Discussion Papers
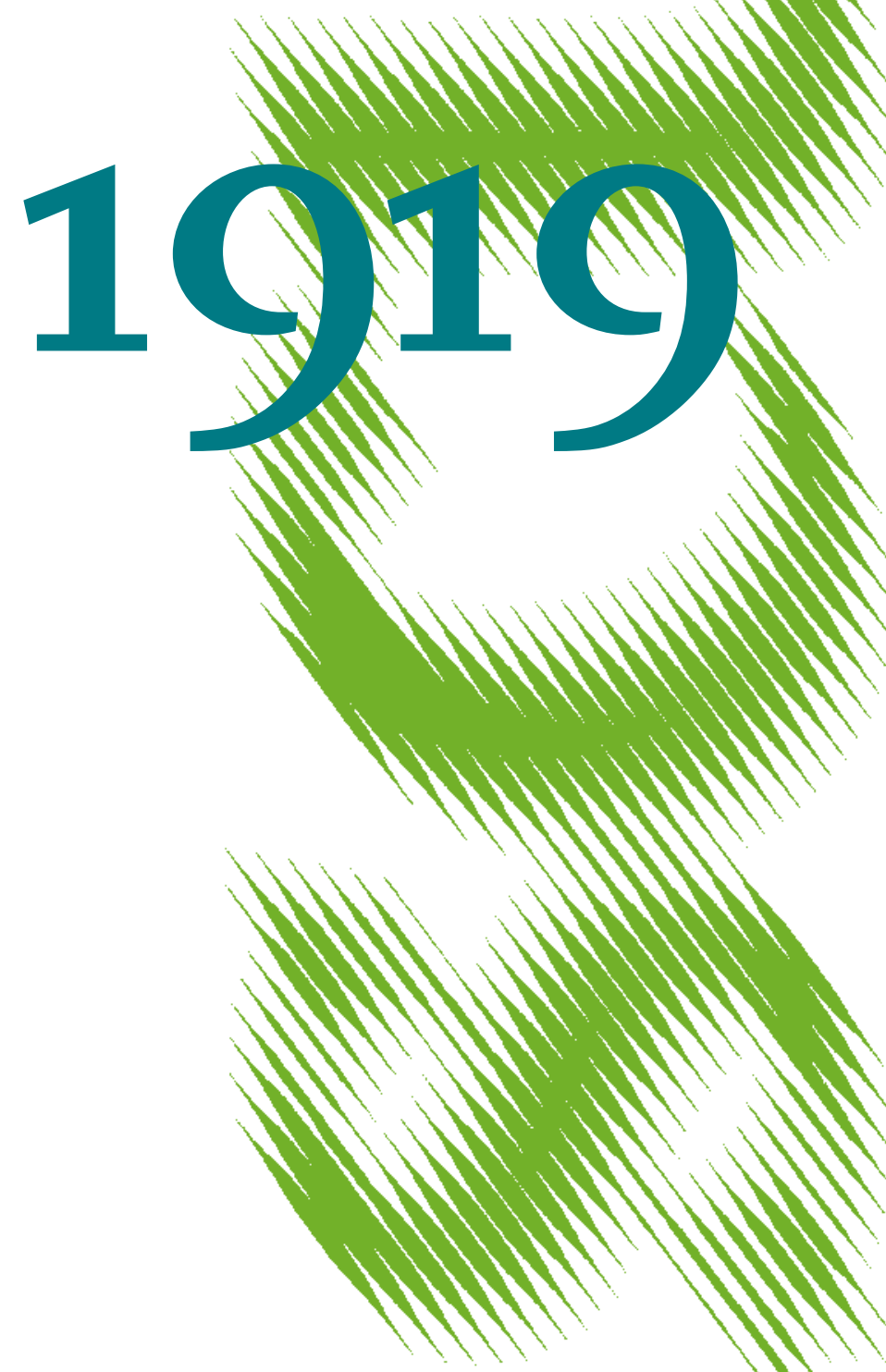

Savings Goal Calendars as Soft Commitment Devices: Evidence from Small Business Owners in Uganda 
Opinions expressed in this paper are those of the author(s) and do not necessarily reflect views of the institute.

IMPRESSUM

(C) DIW Berlin, 2020

DIW Berlin

German Institute for Economic Research

Mohrenstr. 58

10117 Berlin

Tel. +49 (30) $89789-0$

Fax +49 (30) $89789-200$

http://www.diw.de

ISSN electronic edition 1619-4535

Papers can be downloaded free of charge from the DIW Berlin website:

http://www.diw.de/discussionpapers

Discussion Papers of DIW Berlin are indexed in RePEc and SSRN:

http://ideas.repec.org/s/diw/diwwpp.html

http://www.ssrn.com/link/DIW-Berlin-German-Inst-Econ-Res.html 


\title{
Savings Goal Calendars as Soft Commitment Devices: Evidence from Small Business Owners in Uganda
}

\author{
Antonia Grohmann* ${ }^{*}$ Tabea Lakemann ${ }^{\dagger}$ Helke Seitz ${ }^{\ddagger}$
}

September 30, 2020

\begin{abstract}
This study examines the effect of a soft commitment device in the form of a savings goal calendar on savings for small business owners in Kampala, Uganda. We run a randomized controlled trial (RCT) under which the treatment group receives a calendar designed to set savings goals and to make a plan to reach this goal. The control group is given a plain calendar. We find no average effect on savings, but show that present-biased individuals save more when given the calendar. Further examinations indicate that present-biased individuals are more likely to use the calendar, suggesting that, in line with theory, presentbiased individuals have a demand.
\end{abstract}

Keywords: Soft Commitment, Savings, Time Preferences, Small Business Growth JEL codes: O12, D14, D22, C93

\footnotetext{
*Antonia Grohmann, Aarhus University BSS, Fuglesangs Allé 4, 8210 Aarhus, Denmark and German Institute for Economic Research (DIW Berlin); agrohmann@econ.au.dk.

${ }^{\dagger}$ Tabea Lakemann, German Institute for Global and Area Studies (GIGA), 10969 Berlin, Germany; lakemann@giga-hamburg.de.

${ }^{\ddagger}$ Helke Seitz, German Institute for Economic Research (DIW Berlin), 10108 Berlin, Germany; hseitz@diw.de. We appreciate valuable comments from seminars participants in Berlin, the European Economic Association in Rotterdam, Göttingen and Hamburg, in particular: Jann Lay, Lukas Menkhoff, Renate Hartwig and Yuanwei Xu. In particular we thank Jana Hamdan for her intense and valuable support, and Lilly Hock for her excellent research assistance. Financial support by the German Research Foundation (DFG) as well as the "VW Vorab" programme of the Lower Saxony Ministry for Science and Culture is gratefully acknowledged. This field experiment was pre-registered at the AEA RCT Registry on August 28, 2018 (ID: AEARCTR-0003271); see: https://www.socialscienceregistry.org/trials/3271.
} 


\section{Introduction}

A lack of savings prevents small businesses in developing countries from growing. When credit markets are imperfect, savings are often the only option for small business owners to collect enough funds to invest in their business.

Because of this importance of savings for the development and growth of small businesses, a substantial number of studies examine ways to increase savings. These often involve some form of commitment device that locks away money for a certain amount of time or until a certain amount is saved. These hard commitment devices are shown to effectively increase savings for low-income people in low-income settings (Ashraf et al., 2006). The accumulation of savings is especially challenging for individuals who are present-biased. This applies to a substantial number of people, whose preferences are time inconsistent, this leads to lower savings than intended by the current self. As suggested by the name, commitment devices can help sophisticated present-biased individuals, who are aware of their time-inconsistency, to commit to intentions formed by their current self (Thaler and Shefrin, 1981; Laibson, 1997).

Hard commitment devices have a negative side effect as they also lock away liquid funds, which is problematic in the event of an emergency. John $(2020)$ shows, in her study on commitment in the Philippines, that the majority of participants defaults on their commitment savings contract, subsequently incurring a financial cost. This is crucial, as liquidity is key, especially for small-scale entrepreneurs, as formal insurance is essentially absent and savings act as an important form of insurance against shocks. At the same time, the take up of hard commitment devices is often low Ashraf et al., 2006, Karlan et al., 2014), which means that the general increase in savings is low.

An alternative to such hard commitment devices are soft commitment devices. Here, not complying with commitments has psychological rather than financial consequences. Studies of saving behavior in low-income contexts show that soft commitment devices are effective without imposing the same high economic costs of hard commitment devices (Dupas and Robinson, 2013a). At the same time, they provide some flexibility in case of emergency (Karlan et al., 2014).

In this paper, we study the effect of a specific soft commitment device. We design a savings goal calendar wall poster intended to help small business owners achieve a business savings goal. Compared to most other commitment devices, this is a very short and light intervention. At the top of the calendar, business owners can note their savings goal and amount. On the calendar itself, business owners can mark the amount they wish to save on that specific day. At the bottom of the calendar, business owners are encouraged to think about potential obstacles to savings and action plans should these arise. The calendar is based on mental contrasting with implementation intentions (MCII), a concept developed 
by Oettingen and Gollwitzer (2010) to influence behavior, and can be regarded as a soft commitment device. MCII is shown to effectively improve behavior in a number of different domains like engagement in physical activity, education, and labour market reactivation (Stadler et al., 2009, Duckworth et al., 2011, 2013; Berger et al., 2016). In order to test the effectiveness of the soft commitment devise for present-biased individuals, we measure time preferences using an incentivized choice task experiment similar to Meier and Sprenger (2010) and Tanaka et al. (2010).

Soft commitment devices often induce certain behaviors by drawing on one of three things: mental accounting, goal setting, or personal planning. Mental accounting is shown to stop people from withdrawing funds if they are earmarked for a specific purpose (Thaler, 1999). Goal setting is effective in counteracting self-control problems (Koch and Nafziger, 2011; Clark et al., 2020). Lastly, personal plans are also argued to work as soft commitment devices as they help map out actions in detail and impose psychological costs if the plan is not followed (Beshears et al., 2016). The MCII strategy offers a combination of goal setting and a personal plan.

We study the impacts of the savings goal calendar treatment among the owners of small-scale businesses in Kampala, Uganda. These business owners are part of an established panel of entrepreneurs in Kampala. We randomly introduced the savings goal calendar in half of all businesses in our sample. The intervention took place in the business during work hours, where we introduced and explained the calendar to the business owner. The business owners formulated savings goals and thought about obstacles to achieving these savings goals. The wall poster was left with the business owner who could choose if and where to hang it. As each visit took no more than 10 minutes, the intervention was very light. The control group was given a plain calendar as a thank you for taking part in our survey and savings were not discussed.

Kampala, a major hub for small-scale entrepreneurs, is well-suited to study if and how soft commitment devices can improve savings behavior in low-income contexts. Only about $70 \%$ of our respondents report having a bank account. Even those who have a savings account tend to hold cash on a daily basis, which means that the temptation to spend daily earnings is strong. Hence, the need for commitment devices is great. At the same time, most businesses in our sample operate out of fixed locations, which makes a savings intervention like ours more feasible.

We find no average intention-to-treat effects of our savings goal calendar treatment for the full sample on a savings index as well as other saving-related outcomes. In line with theory that presentbiased individuals benefit especially from commitment devices, we test the effect of the savings goal calendar on savings for present-biased individuals. We show that the calendar is effective at increasing savings for this group, although they save less on average.

We further explore a potential mechanism behind these results. We first examine the use of the 
calendar, meaning goal commitment and the perceived usefulness of action plans. We find that only a small group of business owners either have the savings goal calendar present daily, i.e. they put the calendar on a wall in the business or at home, and, only a small proportion perceived the savings goal calendar as useful. However, for these respective groups, the intervention tends to increase savings. To see if differences in use of the calendar explain increased savings for present-biased individuals, we regress our indicator for present bias on calendar location and perceived usefulness of action plans. Results suggest that present-biased individuals are more likely to have the calendar in a visible place and to benefit from the action plan. Therefore, we argue that the savings goal calendar is more effective for present-biased individuals as they are more likely to use it. This is in line with theory suggesting that sophisticated, present-biased individuals demand commitment devices.

Our results provide important insights for the design of interventions aiming to improve savings for small businesses. First, it shows that even a light intervention using a soft commitment device can increase savings for present-biased individuals. Second, it shows that present-biased individuals are the sub-group that is most likely to use these commitment devices. A soft commitment device is effective when there is demand for it and when it is used in the intended manner; hence, the average impact without appropriate targeting may be limited. Consequently, such interventions could be a cheap and easy way to complement longer, more established finance trainings.

This paper contributes to two strands of literature. First, our paper adds to the literature on ways to help low-income groups increase their savings. Many of these papers examine the effect of a safe place to keep money. Dupas et al. (2018) find limited average effects on savings from providing access to bank accounts. However, they find large increases in savings for those who do open a bank account. Brune et al. (2016) find that providing savings accounts to farmers increases agricultural investments by a larger amount than is saved in these accounts. Cole et al. (2011) show that a subsidized bank account is more effective in increasing savings than a very short financial literacy training. Using an experiment in Ethiopia Avdeenko et al. (2019) show that smallholder farmers provided with a moneybox and a regular savings plan increase savings.

Second, our paper adds to the literature on soft commitment devices. The seminal paper by Thaler and Benartzi (2004) shows that large numbers of employees participate in the "save more tomorrow" initiative, which is designed to increase retirement savings rates, at times of pay rises. A substantial number of studies look at commitment devices to increase savings in developing countries. Savings groups that work through peer pressure and goal setting are shown to be very effective at increasing savings (Kast et al. 2018). Similarly, Dupas and Robinson (2013b) find that social pressure is an effective way to increase health savings. They further show that labelling funds for health spending increases savings. In their study, present-biased individuals only increase savings in the social pressure 
setting, which is the strongest commitment device studied. Atkinson et al. (2013) run an experiment during which microfinance borrowers are prompted to either save an open amount or $10 \%$ when repaying their loan. They find increases in savings for both groups, with the group nudged to save $10 \%$ saving significantly more than the control group. A number of papers study soft commitment devices in other settings with a focus on who demands such commitment devices. Bisin and Hyndman (2020) find no average effect of deadline setting for tasks given to students. They attribute this to high levels of partial naiveté and overconfidence. Conversely, Himmler et al. (2019) find that a short pledge is effective in increasing exam participation and course completion within a given schedule. They find that the pledge is most effective for procrastinators. Duflo et al. (2011) argue that farmers with present bias underinvest in fertilizer and show that a small reduction in cost at the time just after harvest can increase fertilizer adoption.

Following this introduction, this papers comprises six additional sections. Section 2 describes the intervention and Section 3 describes the data. Section 4 shows effects for the average sample and present-biased individuals, while Section 5 sheds light on underlying mechanisms. Section 6 provides a sensitivity analysis and Section 7 concludes.

\section{Experimental Design}

This chapter outlines the sampling procedure in Section 2.1, the savings goal intervention in Section 2.2 , followed by its implementation in Section 2.3 .

\subsection{Sampling}

The study took place in Kampala, Uganda's capital, where the intervention was implemented using an annual panel of micro and small enterprises collected between 2012 and 2018. The sample was first drawn by identifying 220 administrative zones with high business activity within Kampala. Out of these, 21 zones were randomly selected for a detailed door-to-door listing of all businesses. Based on a complete listing, businesses were randomly chosen to be part of the panel, taking business strata (services, retail, and manufacturing) into account. As the panel was ongoing for a number of years, some entrepreneurs had changed their business sector.

In April 2018, we collected baseline information and, immediately thereafter, conducted the intervention. Follow-up data were collected six-months later in October 2018. The randomization was based on 501 businesses interviewed in October 2017, with 249 assigned to the treatment group and 252 to the control group (taking into account industry strata and a previously conducted financial training). Out of these, 465 were interviewed and successfully treated in April 2018. In October 2018, 
233 assigned to control and 226 assigned to treatment were contacted during the follow-up.

This sample is not just part of the panel study described above, but also provided the basis for a randomized controlled trial $(\mathrm{RCT})$ that evaluated the effect of an innovative financial training in a previous wave (October 2017). For details of this training see Grohmann et al. (2020). Randomization of the savings goal calendar intervention was orthogonal to implementation of the financial training.

\subsection{Savings Goal Calendar Intervention}

We study the effect of a soft commitment device on savings. It is argued that setting a goal and forming a plan can act as a soft commitment device that imposes a psychological cost if the plan is not stuck to or the goal is not achieved (Bryan et al., 2010; Beshears et al., 2016). The soft commitment device studied in this paper is based on mental contrasting with implementation intentions (MCII). This strategy, developed by Oettingen and Gollwitzer (2010), combines two elements that play different roles in helping people to self-regulate behavior in order to achieve previously set goals. It is previously applied, for example, in the area of education (Duckworth et al., 2011, 2013).

The first part is mental contrasting, which involves participants forming a specific goal in their mind. In settings like education, a goal could be a certain (better) grade in a specific subject. In our setting, we focus on business savings goals. Forming a specific goal is argued to help participants to become more conscious of their goal and helps to focus commitment. Mental contrasting also involves a specific plan on how the desired goal can be reached. In the education setting, this could involve a certain amount of time spent studying every day. In our setting, this involves planning to save a certain amount on a specific day.

The second part of this strategy is implementation intentions. These involve the participants thinking about possible obstacles that could prevent them from reaching their savings goals and forming a plan of action in case such an obstacle arises in an "if. .., then..." format. In the area of education, such an obstacle could be a friend calling asking to go out. The participants will form an implementation intention "If my friend calls asking to go out, then I will tell her that I am busy studying." Similarly, in our setting, we ask participants to imagine potential obstacles that may prevent them from saving and forming an implementation intention in case such an obstacle arises.

\subsection{Implementation}

The treatment as well as a survey questionnaire were both administered in the participant's business. The procedure was as follows: First, the enumerator and business owner jointly filled out the survey questionnaire; second, all respondents were asked for a business related savings goal as well as the amount they need to achieve their goal. The savings goal can be an item that the respondent wants to 
buy for their business or to invest in; it should be achievable within the next weeks or next months. There are no significant differences between the treatment and control groups in terms of the type of savings goals or the savings goal amount (see Appendix Table A.1). Finally, depending on treatment status: the treatment group received a savings goal calendar (a calendar including MCII information) whereas the control group received a plain calendar only covering the next six months.

We designed a calendar aiming to increase business savings by forming a plan and sticking to that plan (shown in Appendix Figure A.1.A). At the top of the calendar, there is a space to fill in the individual savings goal as well as the amount the participant wants to save. To strengthen goal commitment, there is space to reflect on the best thing about reaching the savings goal. The middle part of the calendar is the savings plan toward reaching the goal: here the business owner and the enumerator discussed how much the participant wants to save on which day in order to achieve the savings goal. The enumerator and participant added up the total amount that the participant is planning to save over the six months period that is displayed on the calendar. There was no requirement to achieve the full savings goal within the six months period. The implementation intentions are at the bottom of the calendar. Here, the enumerator and business owner discuss the implementation intentions and fill in the "if..., then..." phrases printed below the calendar. As the total time of the intervention was approximately 10 minutes, it was very short.

The control group received a plain calendar, which was given to them "as a thank you for taking part in our survey" (shown in Appendix Figure A.1.B). They did not receive any instructions regarding savings goals or any other mention of savings.

\section{Data}

This section describes the main outcome variables in Section 3.1, the measurement of time preferences in Section 3.2 , balancing in Section 3.3, and the empirical strategy in Section 3.4 .

\subsection{Outcome Variables}

Our primary outcome variable is a savings index including the following variables: whether someone has any savings, which can be formal savings held in a bank account or with savings and credit cooperative (SACCOs), or informal savings, which can be held with a rotating savings and credit association (ROSCA), at home, with friends and neighbors, or in a mobile money account; the total savings amount; the savings amount that is specifically for the business; the frequency of savings and the savings toward a specific savings goal. We include both the index and the separate variables in our analysis. 


\subsection{Eliciting Time Preferences}

We measure individual time preferences using incentivized choice experiments, an approach that is frequently used in the literature (e.g. Meier and Sprenger, 2010). Using this method, individuals are asked to make decisions over six price lists, which require deciding between smaller rewards in an earlier period $t$ and larger rewards in a later period over two different time frames. While the price lists remain the same, a "near"-term time frame asks between lower amounts in $t$ and higher amounts in $t+1$ month, while a "distant" time frame compares payoffs in 6 to 7 months (the time frames are shown in Appendix Figure A.2.

As an incentive for respondents to reveal their preferences, we provide a financial reward and pay out the individual choice of a randomly drawn panel and row combination. Following the individual choices, a random number generator automatically selects a panel and row for payout, which was presented to the respondent using a tablet device. The payments were made on the specified day using mobile money. To ensure that participants are not just choosing the amount to be paid out sooner because they do not trust that the money will be transferred, all amounts were transferred using mobile money by an employee at our partner institution.

We use the different time frames to measure individual discount factors (IDF) as well as indicators for present bias and future bias. We observe individual IDFs by pinpointing the amount where individuals switch from opting from a smaller, earlier payout to a larger, later payout. We further observe whether individuals' choices are dynamically inconsistent between the near-term and distant-term time frames and, hence, biased toward the future or present. An individual is defined to be present-biased if they are less patient when the smaller, earlier payment is received in the present, and future-biased if they are less patient when the smaller, earlier payment is received in the future. Therefore, we classify individuals as present-biased if $I D F_{\text {near }}<I D F_{\text {distant }}$, and as future-biased if $I D F_{\text {near }}>I D F_{\text {distant }}$. The average $I D F$ of our estimation sample is $0.93,14$ percent are future-biased and 17 percent are present-biased. Our proportion of present-biased individuals is in the mid-range of proportions found in other studies implemented in development contexts like in the Philippines, Malawi, or Nigeria Ashraf et al., 2006; Gine et al., 2016; Janssens et al., 2017; Cassidy and Fafchamps, 2020).

There are a number of different ways to measure time preferences. This elicitation method has a number of advantages, but also a number of disadvantages that may bias the results through different types of measurement problems (Frederick et al., 2002). One frequently discussed problem is the potential of results being influenced by the possibility of arbitrage in capital markets. This is not a concern for us, as most respondents do not have access to financial markets. Similar measures of time preferences can be linked to a large number of household behaviors and financial behavior by low 
income individuals (Bauer et al., 2012).

\subsection{Balancing}

Table 1 provides pre-intervention characteristics assessed during the baseline survey along with pvalues for differences between the control and the treatment group (Column (5)). As the entrepreneurs are randomly assigned to each group, we expect their characteristics to be similar at baseline. Although the randomization was well done using standard software, there are two imbalances regarding entrepreneurial characteristics in our baseline wave: At baseline, the control group is, on average, 1.8 years younger and has capital stocks that are on average 2 million UGX (about 500 USD) higher (Panel A). The savings index is balanced between both groups (Panel B), as are the variables comprising the index (see in Appendix Table A.2. A joint test on orthogonality yields a significant difference between treatment and control group. To take these imbalances into account, individual-level controls are included in our main analysis (following the example of (Crepon et al., 2015)). We present a robustness check without such variables in the Appendix (Panel A of Table A.3); however, results are not sensitive to the inclusion of control variables.

\section{[Insert TABle 1 about here]}

\subsection{Empirical Strategy}

We perform an analysis of covariance (ANCOVA) estimation in order to estimate the causal effect of our savings goal treatment (McKenzie, 2012). This compares outcomes for business owners randomly assigned to the treatment group (savings goal calendar) and to the control group (plain calendar).

We estimate the following equation to obtain unbiased estimates:

$$
y_{i}=\alpha+\beta_{1} \text { Savings Goal Calendar }{ }_{i}+\theta y_{i(t-1)}+X_{i}^{\prime} \gamma+\epsilon_{i}
$$

where $y_{i}$ is the outcome variable, Savings Goal Calendar ${ }_{i}$, indicates assignment to receiving treatment, $y_{i(t-1)}$ is a pre-treatment measure of the outcome variable, and $X_{i}$ is a vector of control variables. We include the strata used for randomization (industry controls and prior treatment assignment) as suggested by Bruhn and McKenzie (2009) and unbalanced baseline variables (age and capital stock). The parameter $\beta_{1}$ gives us the unbiased "intention-to-treat (ITT)" effect that is the effect of being assigned to receiving the savings goal calendar.

In our analysis, we are interested if the overall effect of the treatment on savings related outcomes is significantly different from zero (see Duflo et al. (2007)). Therefore, we aggregate variables belonging to this outcome family to a standardized index following Kling et al. (2007). The index $\mathrm{z}$ is the average 
of all $\mathrm{i}=1, \ldots, \mathrm{I}$ standardized variables belonging to a family of outcomes. Specifically, $z=\frac{1}{I} \sum_{i=1}^{I} z_{i}^{*}$ where $z_{i}^{*}=\frac{y_{i}-\mu_{i}}{\sigma_{i}}, y_{i}$ is an outcome variable, while $\mu_{i}$ and $\sigma_{i}$ are the mean and standard deviation of the respective outcome variable of the control group. We examine the general impact of our treatment (as captured by the indices) as well as the intention-to-treat effect on individual outcomes.

As we are studying the effects of a soft commitment device on savings, we expect it to be most effective for participants who are present-biased, i.e. people who are less patient in the present than in the future. To test this hypothesis, we perform a further regression analysis of heterogeneous effects for present-biased individuals. Hence, we introduce an interaction term between our treatment and being present-biased. In addition, we also control for individual discount rates and future bias (see Ashraf et al., 2006, Meier and Sprenger, 2010). To account for the treatment effect for present-biased individuals, we estimate the following equation:

$$
\begin{aligned}
y_{i}= & \alpha+\beta_{1} \text { Saving Goal Calendar }_{i}+\beta_{2} \text { Saving Goal Calendar }_{i} * \text { Present Bias }_{i} \\
& +\beta_{3} \text { Present Bias }_{i}+\beta_{4} \text { Future Bias }_{i}+\beta_{5} I D F_{i}+\theta y_{i(t-1)}+X_{i}^{\prime} \gamma+\epsilon_{i}
\end{aligned}
$$

where $I D F_{i}$ is the individual discount factor, calculated based on the individual price list, each having a delay length of one month: $I D F=\frac{E}{F}$, where $E$ is the earlier, smaller amount and $F$ is the future, larger amount at which individuals switch from opting for the smaller earlier to the later larger amount 1 Present Bias $_{i}$ is equal to 1 if $I D F_{\text {near }}<I D F_{\text {distant }}$ (less patient if smaller, earlier amount is received in present) and Future Bias $i_{i}$ is equal 1 if $I D F_{\text {near }}>I D F_{\text {distant }}$.

\section{Results}

\subsection{Intention-to-treat Effects}

This section describes the causal treatment effect on savings outcomes based on equation (1). The effects of being assigned to receiving the savings goal calendar on savings related variables six months after the intervention are provided in Table 2, Besides controlling for industry strata, all estimations additionally control for unbalanced variables as discussed in Section 3.3, namely age and capital stock. Column (1) of Table 2 provides the effect on the overall savings index, which can be interpreted as the standardized mean difference between the treatment and control groups. Being assigned to the savings calendar treatment is associated with a savings index 0.031 standard deviation units lower than in the control group, although the effect is not statistically significant. Taking our sample size into consideration, our experiment has 80 percent power to precisely detect effect sizes as small as 0.25

\footnotetext{
${ }^{1} F$ is taken from the last point at which individuals prefer the earlier smaller amount.
} 
standard deviation units (at $\alpha=0.05$ ). Hence, we cannot reject impacts of the treatment below 0.25 standard deviation units. Columns (2) to (8) provide the estimated effects on individual components of the index. As can be seen, none of the variables are significantly influenced by the intervention.

\section{[INSERT TABLE 2 ABOUt HeRE]}

Other variables were registered, for further results see Appendix B, for heterogeneity see Appendix Table A.4.

\subsection{Effects on Present-Biased Individuals}

The savings goal calendar is expected to be most appealing to people who are present-biased and sophisticated, as it is intended to act as a commitment device (Ashraf et al., 2006). These types of people are aware of their time-inconsistent preferences and, therefore, seek a way to commit to their previous good intentions. We are unable to measure sophistication here, but in order to examine whether the savings goal calendar has a stronger effect for present-biased individuals, we estimate equation (2) from Section 3.4. In addition to present bias, we also include measures for future bias and time discounting. Results are shown in Table 3 . We use the same outcome variables as in Table 2.

\section{[InSERT TABLE 3 ABOUt HeRE]}

As suggested by theory, individuals who are present-biased save significantly less. This is confirmed by our empirical findings showing a negative effect of present bias on savings amount related outcome variables. However, the interaction term between present bias and the calendar intervention is positive for all outcome variables and weakly significant for total savings. This suggests that present-biased treatment group entrepreneurs save more than present-biased control group entrepreneurs. Alternatively, one could say that the savings goal calendar mitigates the negative effect of being present-biased. From these regressions, we can also see that individuals with a higher discount rate, meaning that they are less patient, save less. This supports the validity of our measurement of time preferences. The effect of future bias is negative and clearly insignificant.

\section{Mechanism}

As shown previously, we do not find that the treatment increased savings for the sample on average, but find positive, weakly significant effects for present-biased individuals. To understand why the calendar seems to have little effect for many participants, we examine the mechanisms behind these results. Therefore, we analyze the usefulness of the savings goal calendar in general. Concretely, we examine 
the two elements of mental contrasting with implementation intentions which serves as theoretical foundations of the savings goal calendar: mental contrasting, which aims to foster goal commitment; and implementation intentions, the formation of action plans to support goal pursuit. Therefore, we descriptively analyze both elements in Section 5.1. In a next step, we analyze how measures of each element relate to increases in savings in Section 5.2. In Section 5.3, we link these elements to present bias.

\subsection{Descriptives on Goal Commitment and Action Plans}

In this section, we present descriptive evidence on how participants perceived both MCII elements. The first element of the savings goal calendar focused on the commitment and striving for goals (mental contrasting). The second element emphasized action plans for implementation (implementation intentions). We test both elements using self-reported measures six months after treatment implementation.

Focusing on the first element of the intervention, we do not find evidence that the intervention specifically strengthened the commitment of the treatment group toward their savings goal. We use whether the respondent remembers the savings goal and amount, existence and location of the savings goal calendar as proxy measures for goal commitment. Even though the concrete savings goal and corresponding amount were written on top of the savings calendar, the treatment group is not more likely to remember this savings goal itself or the amount six months later, as shown descriptively in Table 4(Panel A, Q1 and Q2). Around 59 percent in the treatment group and 57 percent in the control group correctly remember their specified savings goal, while 55 and 50 percent remember the correct amount, respectively.

\section{[INSERT TABLE 4 ABOUT HeRE]}

One question is if the participants simply did not use the calendar. The suggestion was to post the savings goal calendar on a wall in the business, where respondents spend most of their time. Descriptives show that the treatment group is neither more likely to still have the calendar (Q3) nor more likely to have the savings goal calendar in a more visible place (Q4). Question 4 shows that around 70 percent of respondents, irrespective of treatment or control group, keep the calendar at home. Only 13-16 percent of both groups kept the calendar on a wall in the business, as recommended.

The second element of the treatment, the perceived usefulness of the action plans, shows rather modest results (Panel B of Table 4). We use information on whether the respondent follows the savings plan, perceived the savings plan as helpful and thinking about implementation plans as proxy measures for goal pursuit. This information can only be collected for the treatment group. 
We find that almost half of our respondents state they never followed the savings plan (Q5), hardly found the savings plan helpful (Q6), or hardly found that thinking about strategies to overcome obstacles to saving was helpful (Q7). Overall, only between 14 and 21 percent provide very positive feedback about the usefulness of the action plans (Q5-Q7).

\subsection{Goal Commitment and Action Plans Interacted with Treatment}

In the following, we analyze how the estimated treatment effects vary with differences in goal commitment and perceived usefulness of actions plans. To begin with, we interact measures regarding commitment for the savings goal (Question 1 to Question 4 of Table 4 ) with the treatment indicator and analyze the effect on all savings outcomes. As shown in Table 5 , the treatment effect varies with the location of the savings goal calendar (Q4). The treatment effect is strongest for those who are the most exposed to the savings goal calendar, i.e. when it is on the wall in the business. The coefficient on the interaction term between the treatment and having the calendar posted on the wall at the business 2,154,000 UGX (580 USD) for total savings, subsequently reducing to 1,677,000 UGX (450 USD) if the calendar is anywhere in the business, and turns negative if the calendar is at home. Hence, the marginal treatment effect for those having the calendar on the wall is 1,710,000 UGX (480 USD), which amounts to an economically meaningful increase in total savings of around 83 percent compared to the control mean (of 2,061,000 UGX, see Table 2).

The remaining analyses yield that there is no meaningful variation in treatment effects with respect to other measures of goal commitment such as remembering the savings goal, the goal amount, or still having the calendar.

\section{[INSERT TABLE 5 ABOUt HeRE]}

Further, we analyze if savings outcomes are associated with measures of perceived usefulness of action plans. Again, this analysis is only possible for the treatment group. Table 6 shows that the self-reported usefulness of the action plans is positively, and mostly significantly, associated with all measures of saving except the frequency. This applies to all three measurements of usefulness. Hence, there is a strong and significant correlation between perceiving the calendar as useful and increased savings.

[Insert TABle 6 about here]

\subsection{Association between Present Bias, Goal Commitment and Action Plans}

We now bring together our previous result on the effectiveness of the intervention for present-biased individuals (Section 4.2 ) and the result regarding the effectiveness for respondents having the calendar 
in the business and the perceived usefulness of action plans (Section 5.2). Concretely, we address whether present-biased individuals are more likely to use the calendar fully and, consequently, more likely to have the calendar on their business wall. We are also interested in learning if present-biased individuals are more likely to perceive the action plans as useful.

\section{[INSERT TABle 7 ABOUt here]}

Table 7 shows to what extent present-biased preferences in the treatment group can explain the location of the calendar (Panel A) and the perceived usefulness of action plans (Panel B). From a theoretical perspective, present-biased individuals should have greater demand for the calendar as a commitment device and, thusly, should be more likely to use it. Panel A shows that being present bias is associated with having the calendar on the wall in the business or on the wall at home. A negative relationship is found between present-biased individuals and not having the calendar on the wall (either at the business or at home). While none of the relationships are significant at any conventional significance level, we take these positive coefficients as suggestive evidence. Hence, one potential mechanism why present-biased individuals benefit from the intervention is that they seek a commitment device and, thus, are more likely to follow the instructions and put the calendar on their business wall.

Panel B suggests a positive association between present bias and the tendency to follow the savings plan as well as, surprisingly, a negative association between the usefulness of the savings plans. The first result is in line with theory. The second result is not. One possible explanation is that present-biased individuals simply do not perceive the savings plan as useful.

\section{Sensitivity Analysis}

This section assesses the sensitivity of our main treatment effects by conducting several robustness analyses. A first set of sensitivity checks is found in Table 8. Column (1) of Table 8 provides our main results of Table 2 again for comparability reasons. We first show estimates without controls for unbalanced variables in Column (2), and estimates controlling for unbalanced formal and informal savings in Column (3). Finally, we restrict the sample to respondents who specify a concrete savings goal in Column (4). Comparing the main treatment effect on the savings index to the remaining columns in Table 8 shows that the estimated effects do not change much. We conclude from these results that our main intention-to-treat effects are robust.

[INSERT TABle 8 about here] 
The muted results in our main analysis naturally raise the question of implementation problems. Therefore, we analyze whether the presence of spillover effects can explain muted treatment effects. This scenario can occur if entrepreneurs assigned to receiving the savings goal calendar share information with assigned control group entrepreneurs. In case control group entrepreneurs similarly use the calendar to achieve their savings goal, this would result in the same savings increase compared to the treatment group. In this case, the true treatment effect would be underestimated and our estimate would be a lower bound estimate. To test whether spillovers affect the control group, we analyze whether the share of treated entrepreneurs in a certain radius affects the treatment effect using GPS information. Therefore, we interact the share of treated entrepreneurs in a 10 to 100 meter radius with the treatment indicator. As shown in Table 9, the coefficient of the share treated in the surroundings remains negative and varies in magnitude but never becomes significant. We take this as evidence against spillovers, specifically against the argument that the control group learns from the treatment group to use the calendar as savings commitment device.

\section{[INSERT TABLE 9 ABOUt HeRE]}

\section{Conclusion}

Savings are crucial for micro and small enterprise owners in order to make sufficient investments into their business. While most of the existing literature focuses on physical access to savings devices and on hard commitment devices, this paper focuses on soft commitment devices. In doing so, we analyze the effect of a savings goal calendar that follows the concept of mental contrasting with implementation intentions (MCII), which is designed to foster self-regulated goal commitment. We designed the savings goal calendar as a soft commitment device for small business owners to increase their business related savings.

The intervention was implemented in Kampala, Uganda's capital city, among micro and small enterprise owners. The treatment group received a savings goal calendar, where concrete savings goals and action plans in case of obstacles that would prevent respondents from savings were noted. The wall calendar was left with the owner, who could then choose if and where to hang it. The control group received a plain calendar covering the upcoming six months, with no savings goal information attached.

We find that the intervention does not lead to an average increase in savings. However, we find some evidence that the intervention positively affects savings for present-biased individuals. Examining the mechanism, we find that only a small proportion of participants use the calendar by hanging it on the wall or perceive the action plan as useful, both being associated with higher savings. We find 
suggestive evidence that present-biased individuals are more likely to use the calendar in this manner. This sheds light on one potential explanation why present-biased individuals benefit from the savings goal calendar. In line with theory, this suggests a demand for commitment devices by present-biased individuals.

Although the evidence we find is largely suggestive, some policy lessons can be drawn from our results. A very light savings intervention in the form of a soft commitment device can be effective in increasing savings, but only for a specific group of individuals. These individuals could be pre-selected or specifically targeted if such an intervention were to be scaled up. Since this intervention is very light and inexpensive to implement, it can be added to other savings and finance interventions without great effort. 


\section{References}

Ashraf, N., D. Karlan, and W. Yin (2006). Tying odysseus to the mast: Evidence from a commitment savings product in the Philippines. The Quarterly Journal of Economics 121(2), 635-672.

Atkinson, J., A. De Janvry, C. McIntosh, and E. Sadoulet (2013). Prompting microfinance borrowers to save: A field experiment from Guatemala. Economic Development and Cultural Change 62(1), 21-64.

Avdeenko, A., A. Bohne, and M. Frölich (2019). Linking savings behavior, confidence and individual feedback: A field experiment in Ethiopia. Journal of Economic Behavior $\& 3$ Organization 167, 122 151.

Bauer, M., J. Chytilová, and J. Morduch (2012). Behavioral foundations of microcredit: Experimental and survey evidence from rural India. American Economic Review 102(2), 1118-39.

Berger, E. M., G. Koenig, H. Mueller, F. Schmidt, and D. Schunk (2016). Self-regulation training, labor market reintegration of unemployed individuals, and locus of control - evidence from a natural field experiment. CESifo Working Paper Series 6246, CESifo Group Munich.

Beshears, J., K. L. Milkman, and J. Schwartzstein (2016). Beyond beta-delta: The emerging economics of personal plans. American Economic Review 106(5), 430-34.

Bisin, A. and K. Hyndman (2020). Present-bias, procrastination and deadlines in a field experiment. Games and Economic Behavior 119, 339-357.

Bruhn, M. and D. McKenzie (2009). In pursuit of balance: Randomization in practice in development field experiments. American Economic Journal: Applied Economics 1(4), 200-232.

Brune, L., X. Gine, J. Goldberg, and D. Yang (2016). Facilitating savings for agriculture: Field experimental evidence from Malawi. Economic Development and Cultural Change 64(2), 187-220.

Bryan, G., D. Karlan, and S. Nelson (2010). Commitment devices. Annual Review of Economics 2(1), 671-698.

Cassidy, R. and M. Fafchamps (2020). Banker my neighbour: Matching and financial intermediation in savings groups. Journal of Development Economics 145, 102460.

Clark, D., D. Gill, V. Prowse, and M. Rush (2020). Using goals to motivate college students: Theory and evidence from field experiments. Review of Economics and Statistics, forthcoming.

Cole, S., T. Sampsom, and B. Zia (2011). Prices or knowledge? What drives demand for financial services in emerging markets? The Journal of Finance 66 (6), 1933-1967.

Crepon, B., F. Devoto, E. Duflo, and W. Pariente (2015). Estimating the impact of microcredit on those who take it up: Evidence from a randomized experiment in Morocco. American Economic Journal: Applied Economics 7(1), 123-150.

Duckworth, A., H. Grant, B. Loew, G. Oettingen, and P. Gollwitzer (2011). Self-regulation strategies improve self-discipline in adolescents: Benefits of mental contrasting and implementation intentions. Educational Psychology 31(1), 17-26.

Duckworth, A., T. Kirby, G. Oettingen, and A. Gollwitzer (2013). From fantasy to action: Mental contrasting with implementation intentions (MCII) improves academic performance in children. Social Psychological and Personality Science 4(6), 745-753.

Duflo, E., R. Glennerster, and M. Kremer (2007). Using Randomization in Development Economics Research: A Toolkit, Volume 4 of Handbook of Development Economics, Chapter 61, pp. 3895-3962. Elsevier.

Duflo, E., M. Kremer, and J. Robinson (2011). Nudging farmers to use fertilizer: Theory and experimental evidence from Kenya. American Economic Review 101(6), 2350-2390.

Dupas, P., D. Karlan, J. Robinson, and D. Ubfal (2018). Banking the unbanked? Evidence from three countries. American Economic Journal: Applied Economics 10(2), 257-297. 
Dupas, P. and J. Robinson (2013a). Savings constraints and microenterprise development: Evidence from a field experiment in Kenya. American Economic Journal: Applied Economics 5(1), 163-192.

Dupas, P. and J. Robinson (2013b). Why don't the poor save more? Evidence from health savings experiments. American Economic Review 103(4), 1138-1171.

Frederick, S., G. Loewenstein, and T. O'Donoghue (2002). Time discounting and time preference: A critical review. Journal of Economic Literature 40(2), 351-401.

Gine, X., J. Goldberg, D. Silverman, and D. Yang (2016). Revising commitments: Field evidence on the adjustment of prior choices. The Economic Journal 128(608), 159-188.

Grohmann, A., L. Menkhoff, and H. Seitz (2020). The effect of personalized feedback on small enterprises' finances in Uganda. Economic Development and Cultural Change, forthcoming.

Himmler, O., R. Jäckle, and P. Weinschenk (2019). Soft commitments, reminders, and academic performance. American Economic Journal: Applied Economics 11(2), 114-142.

Janssens, W., B. Kramer, and L. Swart (2017). Be patient when measuring hyperbolic discounting: Stationarity, time consistency and time invariance in a field experiment. Journal of Development Economics 126, 77 - 90.

John, A. (2020). When commitment fails: Evidence from a field experiment. Management Science $66(2), 503-529$.

Karlan, D., A. Ratan, and J. Zinman (2014). Savings by and for the poor: A research review and agenda. Review of Income and Wealth 60(1), 36-78.

Kast, F., S. Meier, and D. Pomeranz (2018). Saving more in groups: Field experimental evidence from Chile. Journal of Development Economics 133, 275-294.

Kling, J. R., J. B. Liebman, and L. F. Katz (2007). Experimental analysis of neighborhood effects. Econometrica 75(1), 83-119.

Koch, A. K. and J. Nafziger (2011). Self-regulation through goal setting. Scandinavian Journal of Economics 113(1), 212-227.

Laibson, D. (1997). Golden eggs and hyperbolic discounting. The Quarterly Journal of Economics 112(2), 443-478.

McKenzie, D. (2012). Beyond baseline and follow-up: The case for more $\mathrm{t}$ in experiments. Journal of Development Economics 99(2), 210-221.

Meier, S. and C. Sprenger (2010). Present-biased preferences and credit card borrowing. American Economic Journal: Applied Economics 2(1), 193-210.

Oettingen, G. and P. Gollwitzer (2010). Strategies of setting and implementing goals: Mental contrasting and implementation intentions. In J. E. Maddux (Ed.), Social psychological foundations of clinical psychology, pp. 114-135. New York: Guilford.

Stadler, G., G. Oettingen, and P. M. Gollwitzer (2009). Physical activity in women: Effects of a self-regulation intervention. American Journal of Preventive Medicine 36 (1), 29-34.

Tanaka, T., C. F. Camerer, and Q. Nguyen (2010, March). Risk and time preferences: Linking experimental and household survey data from Vietnam. American Economic Review 100(1), 557-71.

Thaler, R. H. (1999). Mental accounting matters. Journal of Behavioral decision making 12(3), 183-206.

Thaler, R. H. and S. Benartzi (2004). Save more tomorrow: Using behavioral economics to increase employee saving. Journal of Political Economy 112(S1), 164-187.

Thaler, R. H. and H. M. Shefrin (1981). An economic theory of self-control. Journal of Political Economy 89(2), 392-406. 
Table 1: Pre-Intervention Summary Statistics

\begin{tabular}{|c|c|c|c|c|c|}
\hline & \multirow{2}{*}{$\begin{array}{l}\text { Obs. } \\
(1)\end{array}$} & \multirow{2}{*}{$\begin{array}{c}\text { Full Sample } \\
\text { mean } \\
(\text { sd }) \\
(2) \\
\end{array}$} & \multirow{2}{*}{$\begin{array}{c}\text { Control Group (C) } \\
\text { mean } \\
(\mathrm{sd}) \\
(3) \\
\end{array}$} & \multicolumn{2}{|c|}{ Treatment Group } \\
\hline & & & & $\begin{array}{c}\text { mean } \\
(\mathrm{sd}) \\
(4)\end{array}$ & $\begin{array}{c}\text { Diff. from C } \\
\text { [p-value] } \\
(5)\end{array}$ \\
\hline \multicolumn{6}{|c|}{ Panel A: Socio-economic Characteristics } \\
\hline Age & 458 & $\begin{array}{c}39.01 \\
(10.08)\end{array}$ & $\begin{array}{l}38.13 \\
(9.67)\end{array}$ & $\begin{array}{c}39.92 \\
(10.43)\end{array}$ & $\begin{array}{l}-1.79 \\
{[0.06]}\end{array}$ \\
\hline HH size & 459 & $\begin{array}{c}4.49 \\
(2.40)\end{array}$ & $\begin{array}{c}4.35 \\
(2.40)\end{array}$ & $\begin{array}{c}4.64 \\
(2.40)\end{array}$ & $\begin{array}{l}-0.29 \\
{[0.19]}\end{array}$ \\
\hline Female & 463 & $\begin{array}{c}0.41 \\
(0.49)\end{array}$ & $\begin{array}{c}0.42 \\
(0.50)\end{array}$ & $\begin{array}{c}0.39 \\
(0.49)\end{array}$ & $\begin{array}{c}0.03 \\
{[0.45]}\end{array}$ \\
\hline Higher education $^{a}$ & 459 & $\begin{array}{c}0.34 \\
(0.47)\end{array}$ & $\begin{array}{c}0.36 \\
(0.48)\end{array}$ & $\begin{array}{c}0.31 \\
(0.46)\end{array}$ & $\begin{array}{c}0.05 \\
{[0.24]}\end{array}$ \\
\hline Own-account & 464 & $\begin{array}{c}0.51 \\
(0.50)\end{array}$ & $\begin{array}{c}0.48 \\
(0.50)\end{array}$ & $\begin{array}{c}0.54 \\
(0.50)\end{array}$ & $\begin{array}{l}-0.06 \\
{[0.23]}\end{array}$ \\
\hline Capital stock ${ }^{b}$ & 465 & $\begin{array}{c}4,096.82 \\
(8,977.18)\end{array}$ & $\begin{array}{c}5,098.76 \\
(11,190.15)\end{array}$ & $\begin{array}{c}3,064.25 \\
(5,730.03)\end{array}$ & $\begin{array}{c}2,034.51 \\
{[0.01]}\end{array}$ \\
\hline \multicolumn{6}{|c|}{ Panel B: Outcome Indices } \\
\hline Savings Index & 404 & $\begin{array}{l}-0.01 \\
(0.97)\end{array}$ & $\begin{array}{c}0.00 \\
(1.00)\end{array}$ & $\begin{array}{l}-0.02 \\
(0.94)\end{array}$ & $\begin{array}{c}0.02 \\
{[0.83]}\end{array}$ \\
\hline Investment Index & 443 & $\begin{array}{l}-0.04 \\
(0.92)\end{array}$ & $\begin{array}{c}0.00 \\
(1.00)\end{array}$ & $\begin{array}{l}-0.07 \\
(0.84)\end{array}$ & $\begin{array}{c}0.07 \\
{[0.41]}\end{array}$ \\
\hline
\end{tabular}

Source: Survey on micro and small enterprises in Uganda, wave April 2018, own calculations.

Notes: The table provides summary statistics of baseline data and mean comparisons between the treatment group (savings goal calendar) and control group (plain calendar) in Column (5). Standard deviations are in parenthesis, p-values for differences of means appear in squared brackets. Detailed balancing information for variables belonging to the savings and investment indices are found in Appendix Table A.2

${ }^{a}$ Higher education is a dichotomous variable, where $1=$ upper secondary degree (A-level) and more, and $0=$ lower secondary degree (O-level) and less.

${ }^{b}$ Capital stock is winsorized at the 99 percent level. 
Table 2: Intention-to-Treat Effects on Savings Related Outcomes

\begin{tabular}{|c|c|c|c|c|c|c|c|c|}
\hline & $\begin{array}{l}\text { Savings } \\
\text { Index } \\
(1)\end{array}$ & $\begin{array}{c}\text { Savings } \\
\text { (yes/no) } \\
(2)\end{array}$ & $\begin{array}{c}\text { Savings } \\
\text { Total } \\
(3)\end{array}$ & $\begin{array}{l}\text { Savings } \\
\text { Formal } \\
(4)\end{array}$ & $\begin{array}{c}\text { Savings } \\
\text { Informal } \\
(5)\end{array}$ & $\begin{array}{l}\text { Business } \\
\text { Savings } \\
(6)\end{array}$ & $\begin{array}{c}\text { Frequency } \\
\text { Savings } \\
(7)\end{array}$ & $\begin{array}{c}\text { Savings } \\
\text { Toward Goal } \\
(8)\end{array}$ \\
\hline Saving Goal Calendar & $\begin{array}{c}-.031 \\
(0.088)\end{array}$ & $\begin{array}{c}0.008 \\
(0.028)\end{array}$ & $\begin{array}{l}-219.762 \\
(307.823)\end{array}$ & $\begin{array}{c}7.243 \\
(127.984)\end{array}$ & $\begin{array}{c}-2.155 \\
(37.078)\end{array}$ & $\begin{array}{c}-3.753 \\
(154.285)\end{array}$ & $\begin{array}{c}0.004 \\
(0.069)\end{array}$ & $\begin{array}{l}-127.653 \\
(139.166)\end{array}$ \\
\hline $\mathrm{R}^{2}$ & 0.18 & 0.02 & 0.26 & 0.27 & 0.04 & 0.12 & 0.05 & 0.14 \\
\hline Mean (SD) of & 0.00 & 0.92 & 2061.44 & 1014.10 & 312.81 & 746.38 & 6.63 & 755.93 \\
\hline control group & 1.00 & 0.27 & 4559.71 & 1555.19 & 370.92 & 1929.45 & 0.70 & 1689.29 \\
\hline Obs. & 401.00 & 401.00 & 401.00 & 401.00 & 401.00 & 401.00 & 401.00 & 401.00 \\
\hline control for $y_{(t-1)}$ & yes & yes & yes & yes & yes & yes & yes & yes \\
\hline control for industry strata & yes & yes & yes & yes & yes & yes & yes & yes \\
\hline
\end{tabular}

Source: Survey on micro and small enterprises in Uganda, waves April and October 2018, own calculations.

Notes: The table shows the 6-months follow-up intention-to-treat effects on savings related outcomes. The savings index provided in Column (1) comprises all variables in the remaining columns. Standard errors in parentheses. ${ }^{*} p<0.1{ }^{* *} p<0.05,{ }^{* * *}$ $p<0.01$.

Table 3: Present-biased Preferences and Intention-to-Treat Effects

\begin{tabular}{lcccccccc}
\hline \hline & $\begin{array}{c}\text { Savings } \\
\text { Index } \\
(1)\end{array}$ & $\begin{array}{c}\text { Savings } \\
(\text { yes } / \text { no }) \\
(2)\end{array}$ & $\begin{array}{c}\text { Savings } \\
\text { Total } \\
(3)\end{array}$ & $\begin{array}{c}\text { Savings } \\
\text { Formal } \\
(4)\end{array}$ & $\begin{array}{c}\text { Savings } \\
\text { Informal }\end{array}$ & $\begin{array}{c}\text { Business } \\
\text { Savings } \\
(5)\end{array}$ & $\begin{array}{c}\text { Frequency } \\
\text { Savings } \\
(7)\end{array}$ & $\begin{array}{c}\text { Savings } \\
\text { Toward Goal } \\
(8)\end{array}$ \\
\hline Savings Goal Calendar & -.057 & -.005 & -347.679 & 10.513 & -15.371 & -23.944 & 0.034 & -164.649 \\
& $(0.097)$ & $(0.029)$ & $(351.579)$ & $(144.880)$ & $(40.431)$ & $(175.333)$ & $(0.077)$ & $(151.884)$ \\
SGC * Present-biased & 0.25 & 0.097 & $998.547^{*}$ & 59.632 & 84.198 & 286.345 & -.179 & 364.933 \\
& $(0.225)$ & $(0.085)$ & $(601.047)$ & $(298.182)$ & $(109.845)$ & $(368.773)$ & $(0.212)$ & $(373.815)$ \\
Present-biased & $-.380^{* *}$ & -.093 & $-1944.207^{* * *}$ & $-430.166^{*}$ & -12.271 & $-595.118^{* *}$ & 0.123 & $-477.439^{*}$ \\
& $(0.159)$ & $(0.062)$ & $(660.759)$ & $(232.240)$ & $(83.054)$ & $(292.480)$ & $(0.131)$ & $(278.404)$ \\
Future-biased & -.024 & 0.015 & -409.776 & -180.180 & -34.547 & -27.428 & 0.074 & -87.328 \\
& $(0.168)$ & $(0.038)$ & $(703.810)$ & $(242.227)$ & $(58.558)$ & $(327.769)$ & $(0.155)$ & $(291.925)$ \\
IDF & $-1.355^{* * *}$ & -.029 & $-6158.619^{* *}$ & $-2086.614^{* *}$ & -61.753 & $-2584.673^{* *}$ & 0.15 & $-2070.006^{*}$ \\
& $(0.514)$ & $(0.098)$ & $(2677.750)$ & $(856.090)$ & $(205.460)$ & $(1300.346)$ & $(0.39)$ & $(1102.249)$ \\
Obs. & 400 & 400 & 400 & 400 & 400 & 400 & 400 & 400 \\
\hline \hline
\end{tabular}

Source: Survey on micro and small enterprises in Uganda, waves April and October 2018, own calculations.

Notes: The table shows the 6-months follow-up intention-to-treat effects on savings related outcomes, while the treatment effect is interacted with an indicator for present-biased preferences. It is further controlled for future-biased preferences and individual discount factors (IDF). The savings index provided in Column (1) comprises all variables in the remaining columns. Standard errors in parentheses. ${ }^{*} p<0.1,{ }^{* *} p<0.05,{ }^{* * *} p<0.01$. 
Table 4: Summary Statistics on Measures of MCII Elements

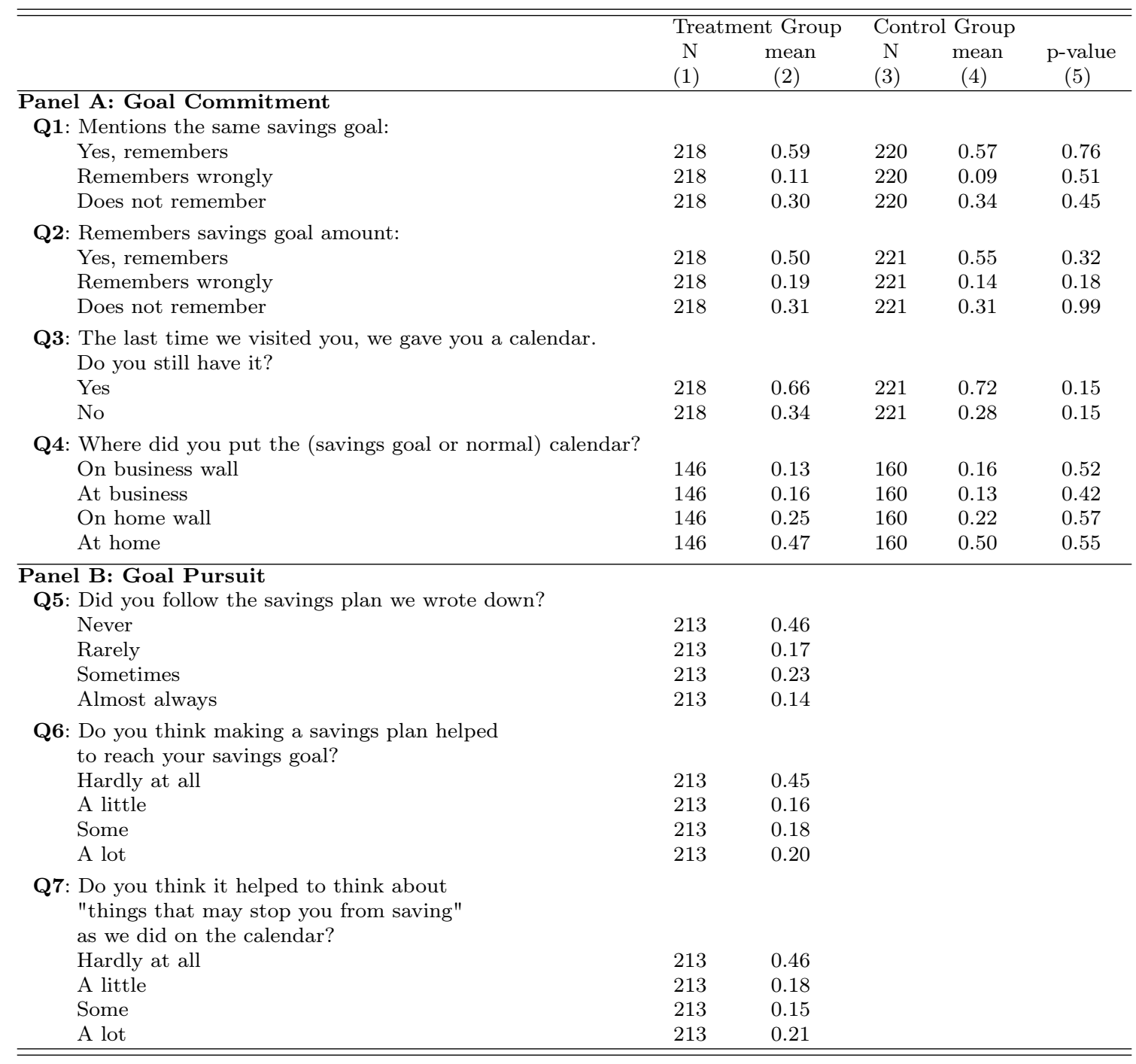

Source: Survey on micro and small enterprises in Uganda, wave October 2018, own calculations.

Notes: The table provides information on the implementation of the intervention. Panel A covers Questions (1)

- (4), which reflect the commitment and striving for goals. Panel B covers Questions (5) - (7) on the helpfulness of implementation plans. 
Table 5: Goal Commitment and Intention-to-Treat Effects

\begin{tabular}{|c|c|c|c|c|c|c|c|c|}
\hline & $\begin{array}{l}\text { Savings } \\
\text { Index } \\
(1) \\
\end{array}$ & $\begin{array}{c}\text { Savings } \\
\text { (yes/no) } \\
(2) \\
\end{array}$ & $\begin{array}{c}\text { Savings } \\
\text { Total } \\
(3) \\
\end{array}$ & $\begin{array}{c}\text { Savings } \\
\text { Formal } \\
(4) \\
\end{array}$ & $\begin{array}{l}\text { Savings } \\
\text { Informal } \\
(5)\end{array}$ & $\begin{array}{c}\text { Business } \\
\text { Savings } \\
(6)\end{array}$ & $\begin{array}{c}\text { Frequency } \\
\text { Savings } \\
(7) \\
\end{array}$ & $\begin{array}{c}\text { Savings } \\
\text { Toward Goal } \\
(8)\end{array}$ \\
\hline \multicolumn{9}{|l|}{ Panel A: Q1 } \\
\hline Savings Goal Calendar & $\begin{array}{l}-.074 \\
(0.13)\end{array}$ & $\begin{array}{l}0.049 \\
(0.053)\end{array}$ & $\begin{array}{l}-450.118 \\
(441.677)\end{array}$ & $\begin{array}{l}-10.708 \\
(188.412)\end{array}$ & $\begin{array}{c}7.976 \\
(55.527)\end{array}$ & $\begin{array}{l}-279.991 \\
(258.106)\end{array}$ & $\begin{array}{l}-.022 \\
(0.109)\end{array}$ & $\begin{array}{l}-325.621^{*} \\
(174.896)\end{array}$ \\
\hline SGC * Mentions same savings goal & $\begin{array}{c}0.075 \\
(0.171)\end{array}$ & $\begin{array}{l}-.073 \\
(0.061)\end{array}$ & $\begin{array}{l}416.668 \\
(597.564)\end{array}$ & $\begin{array}{c}19.879 \\
(252.716)\end{array}$ & $\begin{array}{l}-13.797 \\
(73.547)\end{array}$ & $\begin{array}{l}480.711 \\
(333.544)\end{array}$ & $\begin{array}{c}0.059 \\
(0.148)\end{array}$ & $\begin{array}{l}316.050 \\
(258.348)\end{array}$ \\
\hline Mentions same savings goal & $\begin{array}{c}0.103 \\
(0.124)\end{array}$ & $\begin{array}{l}0.106^{* *} \\
(0.042)\end{array}$ & $\begin{array}{c}292.012 \\
(509.522)\end{array}$ & $\begin{array}{l}318.664^{*} \\
(176.327)\end{array}$ & $\begin{array}{l}58.150 \\
(51.972)\end{array}$ & $\begin{array}{l}-355.968 \\
(244.380)\end{array}$ & $\begin{array}{l}-.193^{*} \\
(0.104)\end{array}$ & $\begin{array}{c}129.674 \\
(193.053)\end{array}$ \\
\hline Obs. & 396 & 396 & 396 & 396 & 396 & 396 & 396 & 396 \\
\hline \multicolumn{9}{|l|}{ Panel B: Q2 } \\
\hline Savings Goal Calendar & $\begin{array}{l}-.044 \\
(0.125)\end{array}$ & $\begin{array}{c}0.003 \\
(0.047)\end{array}$ & $\begin{array}{l}-29.646 \\
(447.554)\end{array}$ & $\begin{array}{c}80.564 \\
(177.330)\end{array}$ & $\begin{array}{l}-12.255 \\
(52.193)\end{array}$ & $\begin{array}{l}-244.003 \\
(231.999)\end{array}$ & $\begin{array}{c}0.033 \\
(0.098)\end{array}$ & $\begin{array}{l}-35.124 \\
(188.357)\end{array}$ \\
\hline SGC * Remembers savings goal amount & $\begin{array}{c}0.045 \\
(0.178)\end{array}$ & $\begin{array}{l}0.015 \\
(0.055)\end{array}$ & $\begin{array}{l}-263.554 \\
(651.702)\end{array}$ & $\begin{array}{l}-101.765 \\
(258.547)\end{array}$ & $\begin{array}{l}21.823 \\
(76.035)\end{array}$ & $\begin{array}{c}465.137 \\
(345.078)\end{array}$ & $\begin{array}{l}-.064 \\
(0.15)\end{array}$ & $\begin{array}{l}-153.965 \\
(273.952)\end{array}$ \\
\hline Remembers savings goal amount & $\begin{array}{c}0.12 \\
(0.125)\end{array}$ & $\begin{array}{c}0.053 \\
(0.039)\end{array}$ & $\begin{array}{c}666.534 \\
(531.328)\end{array}$ & $\begin{array}{l}297.914^{*} \\
(173.127)\end{array}$ & $\begin{array}{l}42.627 \\
(52.610)\end{array}$ & $\begin{array}{l}-196.182 \\
(237.998)\end{array}$ & $\begin{array}{l}-.110 \\
(0.098)\end{array}$ & $\begin{array}{c}258.771 \\
(204.094)\end{array}$ \\
\hline Obs. & 397 & 397 & 397 & 397 & 397 & 397 & 397 & 397 \\
\hline $\begin{array}{l}\text { Panel C: Q3 } \\
\text { Savings Goal Calendar }\end{array}$ & $\begin{array}{l}0.096 \\
(0.175)\end{array}$ & $\begin{array}{c}0.045 \\
(0.068)\end{array}$ & $\begin{array}{l}-169.116 \\
(722.469)\end{array}$ & $\begin{array}{c}148.358 \\
(209.289)\end{array}$ & $\begin{array}{c}70.494 \\
(58.321)\end{array}$ & $\begin{array}{l}-72.190 \\
(287.944)\end{array}$ & $\begin{array}{l}0.021 \\
(0.176)\end{array}$ & $\begin{array}{l}-20.144 \\
(283.703)\end{array}$ \\
\hline SGC * Still has calendar & $\begin{array}{l}-.136 \\
(0.197)\end{array}$ & $\begin{array}{l}-.041 \\
(0.072)\end{array}$ & $\begin{array}{c}18.228 \\
(787.888)\end{array}$ & $\begin{array}{l}-142.643 \\
(258.044)\end{array}$ & $\begin{array}{l}-85.262 \\
(72.803)\end{array}$ & $\begin{array}{l}112.186 \\
(336.523)\end{array}$ & $\begin{array}{l}-.008 \\
(0.192)\end{array}$ & $\begin{array}{l}-130.340 \\
(328.333)\end{array}$ \\
\hline Still has calendar & $\begin{array}{c}0.374^{* * *} \\
(0.143)\end{array}$ & $\begin{array}{l}0.106^{*} \\
(0.055)\end{array}$ & $\begin{array}{c}380.673 \\
(676.509)\end{array}$ & $\begin{array}{l}433.212^{* *} \\
(175.987)\end{array}$ & $\begin{array}{c}194.545^{* * *} \\
(52.855)\end{array}$ & $\begin{array}{l}43.410 \\
(272.999)\end{array}$ & $\begin{array}{l}0.151 \\
(0.15)\end{array}$ & $\begin{array}{c}170.253 \\
(261.211)\end{array}$ \\
\hline Obs. & 397 & 397 & 397 & 397 & 397 & 397 & 397 & 397 \\
\hline \multicolumn{9}{|l|}{ Panel D: Q4 } \\
\hline Savings Goal Calendar & $\begin{array}{l}-.140 \\
(0.142)\end{array}$ & $\begin{array}{l}-.025 \\
(0.034)\end{array}$ & $\begin{array}{c}-444.152 \\
(441.276)\end{array}$ & $\begin{array}{l}-68.856 \\
(229.195)\end{array}$ & $\begin{array}{l}-12.952 \\
(72.969)\end{array}$ & $\begin{array}{c}77.028 \\
(253.744)\end{array}$ & $\begin{array}{l}-.034 \\
(0.083)\end{array}$ & $\begin{array}{l}-168.696 \\
(237.964)\end{array}$ \\
\hline SGC * Calendar on business wall & $\begin{array}{c}0.369 \\
(0.265)\end{array}$ & $\begin{array}{c}0.088 \\
(0.096)\end{array}$ & $\begin{array}{c}2154.328^{* *} \\
(978.498)\end{array}$ & $\begin{array}{l}941.389^{*} \\
(480.986)\end{array}$ & $\begin{array}{l}-129.517 \\
(128.234)\end{array}$ & $\begin{array}{c}206.291 \\
(340.152)\end{array}$ & $\begin{array}{l}-.181 \\
(0.178)\end{array}$ & $\begin{array}{c}448.608 \\
(423.633)\end{array}$ \\
\hline SGC * Calendar at business & $\begin{array}{c}0.372 \\
(0.288)\end{array}$ & $\begin{array}{l}-.016 \\
(0.065)\end{array}$ & $\begin{array}{l}1677.390^{*} \\
(971.229)\end{array}$ & $\begin{array}{c}112.777 \\
(433.512)\end{array}$ & $\begin{array}{c}165.660 \\
(120.164)\end{array}$ & $\begin{array}{l}-254.712 \\
(706.554)\end{array}$ & $\begin{array}{c}0.379 \\
(0.232)\end{array}$ & $\begin{array}{l}-110.033 \\
(401.618)\end{array}$ \\
\hline SGC * Calendar on wall at home & $\begin{array}{l}-.066 \\
(0.269)\end{array}$ & $\begin{array}{c}0.081 \\
(0.074)\end{array}$ & $\begin{array}{l}-788.787 \\
(973.459)\end{array}$ & $\begin{array}{l}-215.471 \\
(400.408)\end{array}$ & $\begin{array}{l}-43.162 \\
(113.504)\end{array}$ & $\begin{array}{l}-271.302 \\
(562.573)\end{array}$ & $\begin{array}{c}0.048 \\
(0.205)\end{array}$ & $\begin{array}{l}-178.824 \\
(475.519)\end{array}$ \\
\hline Calendar on business wall & $\begin{array}{l}-.297^{*} \\
(0.172)\end{array}$ & $\begin{array}{l}-.099 \\
(0.063)\end{array}$ & $\begin{array}{c}-1067.475^{*} \\
(561.374)\end{array}$ & $\begin{array}{c}-550.469^{* *} \\
(259.992)\end{array}$ & $\begin{array}{c}21.696 \\
(93.970)\end{array}$ & $\begin{array}{l}-117.366 \\
(197.589)\end{array}$ & $\begin{array}{l}0.044 \\
(0.12)\end{array}$ & $\begin{array}{l}-95.822 \\
(250.907)\end{array}$ \\
\hline Calendar at business & $\begin{array}{l}-.213 \\
(0.179)\end{array}$ & $\begin{array}{c}0.013 \\
(0.019)\end{array}$ & $\begin{array}{l}-868.736 \\
(532.132)\end{array}$ & $\begin{array}{c}-6.665 \\
(286.365)\end{array}$ & $\begin{array}{c}-180.231^{* *} \\
(77.037)\end{array}$ & $\begin{array}{c}516.198 \\
(451.247)\end{array}$ & $\begin{array}{l}-.279 \\
(0.196)\end{array}$ & $\begin{array}{c}116.800 \\
(346.415)\end{array}$ \\
\hline Calendar on wall at home & $\begin{array}{l}-.020 \\
(0.227)\end{array}$ & $\begin{array}{l}-.091 \\
(0.056)\end{array}$ & $\begin{array}{c}794.133 \\
(892.463)\end{array}$ & $\begin{array}{c}159.745 \\
(310.695)\end{array}$ & $\begin{array}{l}-48.392 \\
(83.868)\end{array}$ & $\begin{array}{c}595.380 \\
(444.509)\end{array}$ & $\begin{array}{l}-.112 \\
(0.117)\end{array}$ & $\begin{array}{c}193.306 \\
(391.255)\end{array}$ \\
\hline Obs. & 287 & 287 & 287 & 287 & 287 & 287 & 287 & 287 \\
\hline
\end{tabular}

Source: Survey on micro and small enterprises in Uganda, waves April and October 2018, own calculations.

Notes: The table shows the 6-months follow-up intention-to-treat effects on savings related outcomes with the treatment indicator interacted with indicators for the association with the treatment. The indicators are defined as following:

Panel A: Mentions same savings goal $=1$ if savings goal is what the person told in wave April 2018; $0=$ saving goal is not what person told in wave April 2018; $0=$ does not remember

Panel B: Remembers savings goal amount $=1$ if savings goal amount is what the person told in wave April 2018; $0=$ saving goal amount is not what person told in wave April 2018; $0=$ does not remember

Panel C: Still has calendar $=1$ if the respondent still has the calendar; $=0$ does not have the calendar anymore.

Panel D: Calendar on business wall $=1$ if the respondent put the calendar on the business wall; $0=$ else; Calendar at business $=1$ if the calendar is at the business but not on wall; $0=$ else; Calendar on wall at home $=1$ if calendar is on wall at home; $0=$ else. The reference category is the calendar is at home but not on the wall.

The savings index provided in Column (1) comprises all variables in the remaining columns. Standard errors in parentheses. ${ }^{*} p<0.1,{ }^{* *} p<0.05$, $* * * \quad p<0.01$. 
Table 6: Action Plans and Intention-to-Treat Effects

\begin{tabular}{|c|c|c|c|c|c|c|c|c|}
\hline & $\begin{array}{l}\text { Savings } \\
\text { Index } \\
(1)\end{array}$ & $\begin{array}{c}\text { Savings } \\
\text { (yes/no) } \\
(2)\end{array}$ & $\begin{array}{c}\text { Savings } \\
\text { Total } \\
(3)\end{array}$ & $\begin{array}{c}\text { Savings } \\
\text { Formal } \\
(4)\end{array}$ & $\begin{array}{c}\text { Savings } \\
\text { Informal } \\
(5)\end{array}$ & $\begin{array}{l}\text { Business } \\
\text { Savings } \\
(6)\end{array}$ & $\begin{array}{l}\text { Frequency } \\
\text { Savings } \\
(7)\end{array}$ & $\begin{array}{c}\text { Savings } \\
\text { Toward Goal } \\
(8)\end{array}$ \\
\hline $\begin{array}{l}\text { Panel A } \\
\text { Following Savings Plan }\end{array}$ & $\begin{array}{l}0.126^{* *} \\
(0.051)\end{array}$ & $\begin{array}{c}-1.95 \mathrm{e}-18 \\
(4.38 \mathrm{e}-18)\end{array}$ & $\begin{array}{c}369.383^{* * *} \\
(140.397)\end{array}$ & $\begin{array}{l}167.039^{*} \\
(86.799)\end{array}$ & $\begin{array}{l}43.549^{* *} \\
(21.951)\end{array}$ & $\begin{array}{c}184.310^{* *} \\
(86.595)\end{array}$ & $\begin{array}{l}-.015 \\
(0.059)\end{array}$ & $\begin{array}{c}212.572^{* *} \\
(84.592)\end{array}$ \\
\hline Obs. & 191 & 191 & 191 & 191 & 191 & 191 & 191 & 191 \\
\hline $\begin{array}{l}\text { Panel B } \\
\text { Savings Plan Helpful }\end{array}$ & $\begin{array}{c}0.133^{* * *} \\
(0.048)\end{array}$ & $\begin{array}{l}-1.39 \mathrm{e}-19 \\
(4.25 \mathrm{e}-18)\end{array}$ & $\begin{array}{c}299.845^{* *} \\
(125.443)\end{array}$ & $\begin{array}{c}181.289^{* * *} \\
(83.297)\end{array}$ & $\begin{array}{l}38.137^{*} \\
(20.888)\end{array}$ & $\begin{array}{c}220.189^{* *} \\
(100.946)\end{array}$ & $\begin{array}{l}0.007 \\
(0.045)\end{array}$ & $\begin{array}{c}183.259^{* * *} \\
(68.510)\end{array}$ \\
\hline Obs. & 191 & 191 & 191 & 191 & 191 & 191 & 191 & 191 \\
\hline $\begin{array}{l}\text { Panel C } \\
\text { Thought about Action Plans }\end{array}$ & $\begin{array}{c}0.149^{* * *} \\
(0.053)\end{array}$ & $\begin{array}{c}-3.66 \mathrm{e}-18 \\
(4.26 \mathrm{e}-18)\end{array}$ & $\begin{array}{c}394.565^{* *} \\
(163.896)\end{array}$ & $\begin{array}{c}190.759^{* *} \\
(78.842)\end{array}$ & $\begin{array}{l}47.820^{* *} \\
(22.627)\end{array}$ & $\begin{array}{c}223.066^{* *} \\
(93.929)\end{array}$ & $\begin{array}{c}0.021 \\
(0.048)\end{array}$ & $\begin{array}{c}175.566^{* *} \\
(81.786)\end{array}$ \\
\hline Obs. & 191 & 191 & 191 & 191 & 191 & 191 & 191 & 191 \\
\hline
\end{tabular}

Source: Survey on micro and small enterprises in Uganda, waves April and October 2018, own calculations.

Notes: The table shows effects of implementation intentions on savings-related outcomes, while Panel A estimates the effect of Following the Savings Plan, Panel B estimates the effect of Whether the Savings Plan was Helpful and Panel C of whether The respondent thought about implementation plans on savings outcomes.

Standard errors in parentheses. ${ }^{*} p<0.1,{ }^{* *} p<0.05,{ }^{* * *} p<0.01$. 
Table 7: Effect of Present Bias on Calendar Location

\begin{tabular}{|c|c|c|c|c|}
\hline & $(1)$ & $(2)$ & $(3)$ & $(4)$ \\
\hline \multicolumn{5}{|c|}{ Panel A: Location of the Calendar } \\
\hline Present bias & $\begin{array}{c}0.011 \\
(0.076)\end{array}$ & $\begin{array}{l}0.025 \\
(0.074)\end{array}$ & $\begin{array}{l}0.033 \\
(0.08)\end{array}$ & $\begin{array}{l}0.042 \\
(0.079)\end{array}$ \\
\hline IDF & $(0.101)$ & $(0.101)$ & $\begin{array}{l}-.269 \\
(0.361)\end{array}$ & $\begin{array}{l}-.301 \\
(0.36)\end{array}$ \\
\hline Future bias & $\begin{array}{l}0.115 \\
(0.109)\end{array}$ & $\begin{array}{l}0.097 \\
(0.107)\end{array}$ & $\begin{array}{l}0.063 \\
(0.105)\end{array}$ & $\begin{array}{l}0.068 \\
(0.103)\end{array}$ \\
\hline Obs. & 136 & 135 & 135 & 135 \\
\hline \multicolumn{5}{|c|}{ Dependent Variable: Indicator Calendar at business (not on wall) } \\
\hline Present bias & $\begin{array}{cc}0.004 \\
(0.074)\end{array}$ & $\begin{array}{l}-.013 \\
(0.08)\end{array}$ & $\begin{array}{l}-.043 \\
(0.09)\end{array}$ & $\begin{array}{l}-.039 \\
(0.091)\end{array}$ \\
\hline IDF & $\begin{array}{c}0.271 \\
(0.189)\end{array}$ & $\begin{array}{l}0.286^{*} \\
(0.16)\end{array}$ & $\begin{array}{l}0.201 \\
(0.215)\end{array}$ & $\begin{array}{c}0.229 \\
(0.231)\end{array}$ \\
\hline Future bias & $\begin{array}{l}-.007 \\
(0.094)\end{array}$ & $\begin{array}{l}-.006 \\
(0.09)\end{array}$ & $\begin{array}{l}-.036 \\
(0.094)\end{array}$ & $\begin{array}{l}-.021 \\
(0.1)\end{array}$ \\
\hline Obs. & 136 & 135 & 135 & 135 \\
\hline \multicolumn{5}{|c|}{ Dependent Variable: Indicator Calendar on wall at home } \\
\hline Present bias & $\begin{array}{cc}0.202 \\
(0.131)\end{array}$ & $\begin{array}{c}0.178 \\
(0.138)\end{array}$ & $\begin{array}{l}0.214 \\
(0.134)\end{array}$ & $\begin{array}{l}0.205 \\
(0.137)\end{array}$ \\
\hline IDF & $\begin{array}{l}-.027 \\
(0.438)\end{array}$ & $\begin{array}{c}0.026 \\
(0.478)\end{array}$ & $\begin{array}{c}0.114 \\
(0.393)\end{array}$ & $\begin{array}{c}0.119 \\
(0.407)\end{array}$ \\
\hline Future bias & $\begin{array}{l}-.116 \\
(0.115)\end{array}$ & $\begin{array}{l}-.113 \\
(0.112)\end{array}$ & $\begin{array}{l}-.079 \\
(0.107)\end{array}$ & $\begin{array}{l}-.093 \\
(0.108)\end{array}$ \\
\hline Obs. & 136 & 135 & 135 & 135 \\
\hline \multicolumn{5}{|c|}{ Dependent Variable: Indicator Calendar at home (not on wall) } \\
\hline Present bias & $\begin{array}{l}-.217 \\
(0.136)\end{array}$ & $\begin{array}{l}-.190 \\
(0.141)\end{array}$ & $\begin{array}{l}-.204 \\
(0.15)\end{array}$ & $(-.208)$ \\
\hline IDF & $\begin{array}{l}-.142 \\
(0.478)\end{array}$ & $(-.211)$ & $(-.047)$ & $(-.047)$ \\
\hline Future bias & $\begin{array}{c}0.007 \\
(0.153)\end{array}$ & $\begin{array}{c}0.021 \\
(0.155)\end{array}$ & $\begin{array}{c}0.052 \\
(0.163)\end{array}$ & $\begin{array}{c}0.046 \\
(0.168)\end{array}$ \\
\hline Obs. & 136 & 135 & 135 & 135 \\
\hline \multicolumn{5}{|c|}{$\begin{array}{l}\text { Panel B: Action Plans } \\
\text { Dependent Variable: Following Savings Plan }\end{array}$} \\
\hline Present bias & $\begin{array}{c}0.028 \\
(0.283)\end{array}$ & $\begin{array}{l}0.178 \\
(0.263)\end{array}$ & $\begin{array}{l}0.175 \\
(0.278)\end{array}$ & $\begin{array}{l}0.207 \\
(0.283)\end{array}$ \\
\hline IDF & $\begin{array}{l}-1.315 \\
(0.917)\end{array}$ & $(-.906)$ & $\begin{array}{l}-1.146 \\
(0.96)\end{array}$ & $\begin{array}{l}-1.145 \\
(0.99)\end{array}$ \\
\hline Future bias & $\begin{array}{l}-.167 \\
(0.272)\end{array}$ & $(-.176)$ & $\begin{array}{l}-.225 \\
(0.264)\end{array}$ & $\begin{array}{l}-.212 \\
(0.28)\end{array}$ \\
\hline Obs. & 192 & 190 & 190 & 190 \\
\hline \multicolumn{5}{|c|}{ Dependent Variable: Savings Plan Helpful } \\
\hline Present bias & $\begin{array}{l}-.175 \\
(0.276)\end{array}$ & $\begin{array}{l}-.048 \\
(0.282)\end{array}$ & $\begin{array}{l}-.056 \\
(0.297)\end{array}$ & $\begin{array}{l}-.059 \\
(0.303)\end{array}$ \\
\hline IDF & $\begin{array}{c}-1.644^{* *} \\
(0.827)\end{array}$ & $\begin{array}{l}-1.295 \\
(0.847)\end{array}$ & $\begin{array}{l}-1.619^{*} \\
(0.919)\end{array}$ & $\begin{array}{l}-1.618^{*} \\
(0.922)\end{array}$ \\
\hline Future bias & $\begin{array}{l}-.242 \\
(0.289)\end{array}$ & $\begin{array}{l}-.249 \\
(0.287)\end{array}$ & $(-.307)$ & $(-.304)$ \\
\hline Obs. & 192 & 190 & 190 & 190 \\
\hline \multicolumn{5}{|c|}{ Dependent Variable: Thought about Action Plans } \\
\hline Present bias & $\begin{array}{l}-.164 \\
(0.299)\end{array}$ & $\begin{array}{l}-.074 \\
(0.297)\end{array}$ & $\begin{array}{l}-.039 \\
(0.29)\end{array}$ & $\begin{array}{l}-.025 \\
(0.291)\end{array}$ \\
\hline IDF & $\begin{array}{c}-1.961^{* *} \\
(0.896)\end{array}$ & $\begin{array}{l}-1.740^{*} \\
(0.973)\end{array}$ & $\begin{array}{l}-1.717^{*} \\
(0.899)\end{array}$ & $\begin{array}{l}-1.710^{*} \\
(0.885)\end{array}$ \\
\hline Future bias & $\begin{array}{l}-.390 \\
(0.272)\end{array}$ & $(0.276)$ & $\begin{array}{l}-.376 \\
(0.274)\end{array}$ & $\begin{array}{l}-.348 \\
(0.282)\end{array}$ \\
\hline Obs. & 192 & 190 & 190 & 190 \\
\hline \multicolumn{5}{|l|}{ Control for } \\
\hline Present bias & $\checkmark$ & $\checkmark$ & $\checkmark$ & $\checkmark$ \\
\hline Socio-econor & mic Characteristics & $\checkmark$ & $\checkmark$ & $\checkmark$ \\
\hline Firm Charac & cteristics & & $\checkmark$ & $\checkmark$ \\
\hline Previous Tre & eatment & & & $\checkmark$ \\
\hline
\end{tabular}

Source: Survey on micro and small enterprises in Uganda, waves April and October 2018, own calculations.

Notes: The table shows estimates of the effect of present-biased preferences on the location of the calendar (Panel A) and on the implementation intentions of the intervention (Panel B). All estimations control for individual discount factors $(I D F)$ and an indicator for future bias. ${ }^{*} p<0.1$, Standard errors in parentheses. ${ }^{* *} p<0.05,{ }^{* * *} p<0.01$. 
Table 8: Sensitivity Analyses: Savings Index

\begin{tabular}{|c|c|c|c|c|}
\hline & \multicolumn{4}{|c|}{ Savings } \\
\hline & $\begin{array}{l}\text { Index } \\
(1)\end{array}$ & $\begin{array}{l}\text { Index } \\
(2)\end{array}$ & $\begin{array}{l}\text { Index } \\
\text { (3) }\end{array}$ & $\begin{array}{l}\text { Index } \\
(4)\end{array}$ \\
\hline Savings Goal Calendar & $\begin{array}{c}-.031 \\
(0.088)\end{array}$ & $\begin{array}{c}-.069 \\
(0.086)\end{array}$ & $\begin{array}{l}-.013 \\
(0.086)\end{array}$ & $\begin{array}{l}-.067 \\
(0.086)\end{array}$ \\
\hline Obs. & 401 & 404 & 401 & 394 \\
\hline $\begin{array}{l}\text { Sensitivity checks } \\
\text { No control for unbalanced variables } \\
\text { Additionally controlling for unbalanced savings variables } \\
\text { Sample restriction to those with savings goal }\end{array}$ & & $\checkmark$ & $\checkmark$ & $\checkmark$ \\
\hline $\begin{array}{l}\text { Source: Survey on micro and small enterprises in Ugan } \\
\text { calculations. } \\
\text { Notes: The main estimation result is presented in Colum } \\
\text { the following sensitivity analyses: } \\
\text { Column (2): no control for unbalanced variables of previo } \\
\text { Column (3): control for unbalanced savings variables } \\
\text { Column (4): restricting sample to those having a concrete } \\
\text { Standard errors in parentheses. }{ }^{*} p<0.1,{ }^{* *} p<0.05 \text {, }\end{array}$ & $\begin{array}{l}\text { a, waves } \\
\text { (1) and } \\
\text { s treatm } \\
\text { savings } 9 \\
p<0.01\end{array}$ & $\begin{array}{l}\text { April an } \\
\text { he remai }\end{array}$ & $\begin{array}{l}\text { October } \\
\text { ng colun }\end{array}$ & $\begin{array}{l}018 \text {, own } \\
\text { s provide }\end{array}$ \\
\hline
\end{tabular}

Table 9: Main Effects Saving Goal Calendar: Savings

\begin{tabular}{|c|c|c|c|c|}
\hline & $\begin{array}{l}\text { Savings } \\
\text { Index } \\
(1)\end{array}$ & $\begin{array}{l}\text { Savings } \\
\text { Index } \\
(2)\end{array}$ & $\begin{array}{c}\text { Savings } \\
\text { Index } \\
(3)\end{array}$ & $\begin{array}{c}\text { Savings } \\
\text { Index } \\
(4)\end{array}$ \\
\hline $\begin{array}{l}\text { Panel A: Spillover Effects: 10m radius } \\
\text { Savings Goal Calendar }\end{array}$ & $\begin{array}{l}-.054 \\
(0.089)\end{array}$ & & & \\
\hline Savings Goal Calendar $*$ Share treated in $10 \mathrm{~m}$ radius & $\begin{array}{l}18.607 \\
(17.032)\end{array}$ & & & \\
\hline Share treated in $10 \mathrm{~m}$ radius & $\begin{array}{l}-6.178 \\
(10.254)\end{array}$ & & & \\
\hline Obs. & 401 & & & \\
\hline $\begin{array}{l}\text { Panel B: Spillover Effects: } 25 \mathrm{~m} \text { radius } \\
\text { Savings Goal Calendar }\end{array}$ & & $\begin{array}{l}-.064 \\
(0.099)\end{array}$ & & \\
\hline Savings Goal Calendar $*$ Share treated in $25 \mathrm{~m}$ radius & & $\begin{array}{l}4.332 \\
(4.872)\end{array}$ & & \\
\hline Share treated in $25 \mathrm{~m}$ radius & & $\begin{array}{l}-3.781 \\
(3.008)\end{array}$ & & \\
\hline Obs. & & 401 & & \\
\hline $\begin{array}{l}\text { Panel C: Spillover Effects: } \mathbf{7 5 m} \text { radius } \\
\text { Savings Goal Calendar }\end{array}$ & & & $\begin{array}{c}0.054 \\
(0.116)\end{array}$ & \\
\hline Savings Goal Calendar $*$ Share treated in $75 \mathrm{~m}$ radius & & & $\begin{array}{l}-2.778 \\
(2.303)\end{array}$ & \\
\hline Share treated in $75 \mathrm{~m}$ radius & & & $(1.430)$ & \\
\hline Obs. & & & 401 & \\
\hline $\begin{array}{l}\text { Panel D: Spillover Effects: } 100 \mathrm{~m} \text { radius } \\
\text { Savings Goal Calendar }\end{array}$ & & & & $\begin{array}{c}0.072 \\
(0.124)\end{array}$ \\
\hline Savings Goal Calendar * Share treated in $100 \mathrm{~m}$ radius & & & & $\begin{array}{l}-2.488 \\
(2.033)\end{array}$ \\
\hline Share treated in $100 \mathrm{~m}$ radius & & & & $\begin{array}{l}-.306 \\
(1.302)\end{array}$ \\
\hline Obs. & & & & 401 \\
\hline
\end{tabular}

Source: Survey on micro and small enterprises in Uganda, waves April and October 2018, own calculations.

Notes: The table shows the results of a spillover analysis, where we interact the treatment indicator with the share of treated in a certain radius: $10 \mathrm{~m}$ (Panel A), 25m (Panel B), 75m (Panel C), 100 (Panel D). Standard errors in parentheses. ${ }^{*} p<0.1,{ }^{* *} p<0.05,{ }^{* * *} p<0.01$. 
Appendix to

"The Impact of a Savings Goal Calendar Treatment in Uganda" by Antonia Grohmann, Tabea Lakemann, and Helke Seitz

Appendix A: Figure A.1- A.4

Supplementary figures and tables for the main text

Appendix B: Tables B.1- B.6

Supplementary tables for secondary outcomes 
Appendix A 


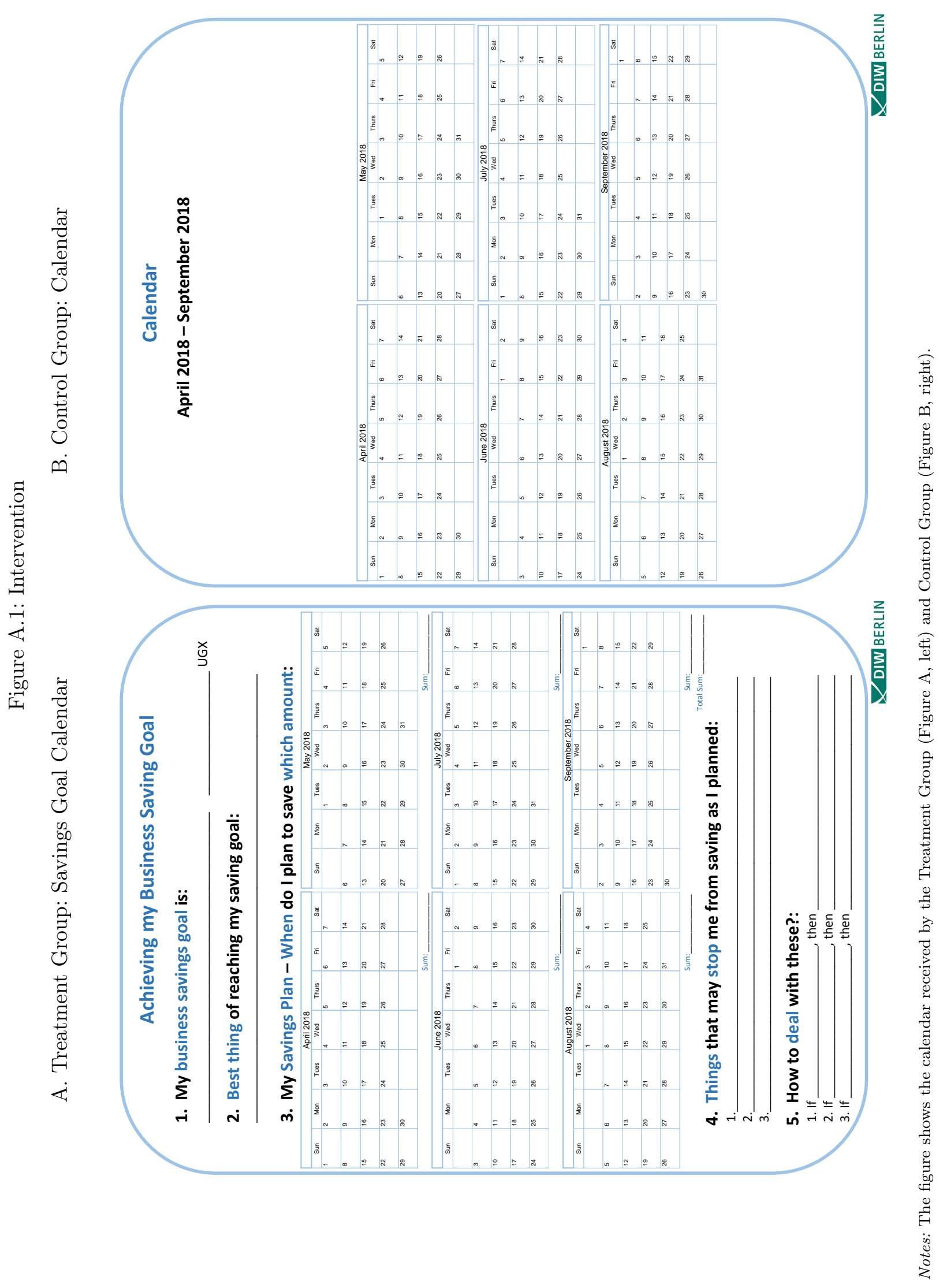


Figure A.2: Elicitation of individual time preferences

Game 2

\begin{tabular}{|c|c|c|c|c|c|c|}
\hline \multicolumn{7}{|l|}{ Panel 1} \\
\hline & Row & \multicolumn{2}{|c|}{ Option A } & Respondents Choice & \multicolumn{2}{|c|}{ Option B } \\
\hline & 1 & 10000 & tomorrow & & 11500 & in 1 month \\
\hline & 2 & 10000 & tomorrow & & 13000 & in 1 month \\
\hline & 3 & 10000 & tomorrow & & 15000 & in 1 month \\
\hline & 4 & 10000 & tomorrow & & 17500 & in 1 month \\
\hline & 5 & 10000 & tomorrow & & 20000 & in 1 month \\
\hline & 6 & 10000 & tomorrow & & 22500 & in 1 month \\
\hline
\end{tabular}

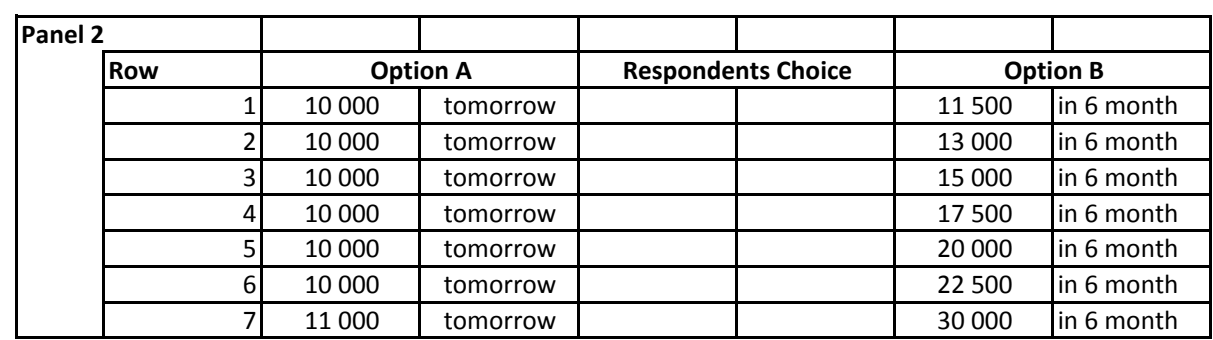

\begin{tabular}{|c|c|c|c|c|c|}
\hline \multicolumn{6}{|l|}{ Panel 3} \\
\hline Row & \multicolumn{2}{|c|}{ Option A } & Respondents Choice & \multicolumn{2}{|c|}{ Option B } \\
\hline 1 & 10000 & in 6 month & & 11500 & in 7 month \\
\hline 2 & 10000 & in 6 month & & 13000 & in 7 month \\
\hline 3 & 10000 & in 6 month & & 15000 & in 7 month \\
\hline 4 & 10000 & in 6 month & & 17500 & in 7 month \\
\hline 5 & 10000 & in 6 month & & 20000 & in 7 month \\
\hline 6 & 10000 & in 6 month & & 22500 & in 7 month \\
\hline
\end{tabular}

Notes: The figure shows choice sets in three different panels to elicit individual time preferences. In each row of each panel, the respondent must choose between a sooner, smaller amount (Option A), or a larger, later amount (Option B). 
Table A.1: Savings Goals

\begin{tabular}{lcccc}
\hline \hline & $\begin{array}{c}\text { All } \\
(1)\end{array}$ & $\begin{array}{c}\text { Treatment Group } \\
(2)\end{array}$ & $\begin{array}{c}\text { Control Group } \\
(3)\end{array}$ & $\begin{array}{c}\text { p-value } \\
(4)\end{array}$ \\
\hline Panel A: Savings Goals by Category & & & & \\
$\quad$ Stock & 149 & 74 & 75 & 0.90 \\
Equipment & 213 & 101 & 112 & 0.47 \\
Premises & 40 & 18 & 22 & 0.58 \\
Investment & 14 & 8 & 6 & 0.55 \\
New firm & 32 & 22 & 10 & 0.02 \\
No goal & 17 & 6 & 11 & 0.24 \\
Panel B: Savings Goal Amounts & 5.009 & 5.027 & 4.992 & 0.97 \\
$\quad$ Business Goal Amount & & & & \\
\hline \hline
\end{tabular}

Source: Survey on micro and small enterprises in Uganda, wave April 2018, own calculations. Notes: The table provides summary statistics on the respondents' savings goals (Panel A) and the associated amounts (Panel B). Panel A provides the number of savings goals by the following categories: Stock (raw materials and finished goods), equipment (business equipment that is used during production process or provision of services (e.g. machines, furniture)), premises (investments related to buying land, plots, premises or renovation), investments (related to the present firm), new firm (investments related to starting another or additional business), and lastly, respondents that do not have a savings goal. Panel B provides the amount in UGX associated with the savings goals by the control and treatment group.

Table A.2: Pre-Intervention Summary Statistics on Savings

\begin{tabular}{|c|c|c|c|c|c|}
\hline & \multirow{4}{*}{$\begin{array}{l}\text { Obs. } \\
(1)\end{array}$} & \multirow{4}{*}{$\begin{array}{l}\text { Full Sample } \\
\text { mean } \\
(\mathrm{sd}) \\
(2)\end{array}$} & \multirow{4}{*}{$\begin{array}{c}\text { Control Group }(\mathrm{C}) \\
\text { mean } \\
(\mathrm{sd}) \\
(3)\end{array}$} & \multicolumn{2}{|c|}{ Treatment Group } \\
\hline & & & & mean & Diff. from $\mathrm{C}$ \\
\hline & & & & (sd) & [p-value] \\
\hline & & & & (4) & (5) \\
\hline \multirow[t]{2}{*}{ Any Savings } & 465 & 0.89 & 0.89 & 0.89 & 0.01 \\
\hline & & $(0.31)$ & $(0.31)$ & $(0.32)$ & {$[0.79]$} \\
\hline \multirow[t]{2}{*}{ Total Savings } & 465 & $1,465.68$ & $1,520.85$ & $1,408.82$ & 112.03 \\
\hline & & $(2,574.31)$ & $(2,857.04)$ & $(2,251.00)$ & {$[0.64]$} \\
\hline \multirow[t]{2}{*}{ Formal Savings } & 465 & 951.47 & 997.43 & 904.11 & 93.31 \\
\hline & & $(1,592.32)$ & $(1,713.44)$ & $(1,459.27)$ & {$[0.53]$} \\
\hline \multirow[t]{2}{*}{ Informal Savings } & 465 & 328.14 & 284.86 & 372.74 & -87.88 \\
\hline & & $(563.50)$ & $(430.48)$ & $(671.77)$ & {$[0.09]$} \\
\hline \multirow[t]{2}{*}{ Business } & 465 & 511.62 & 540.81 & 481.53 & 59.29 \\
\hline & & $(1,573.50)$ & $(1,735.79)$ & $(1,389.74)$ & {$[0.69]$} \\
\hline \multirow[t]{2}{*}{ Frequency } & 443 & 1.65 & 1.67 & 1.62 & 0.04 \\
\hline & & $(1.01)$ & (1.08) & $(0.95)$ & {$[0.66]$} \\
\hline \multirow[t]{2}{*}{ Savings Goal } & 443 & 528.52 & 487.02 & 571.35 & -84.33 \\
\hline & & $(1,163.58)$ & $(1,181.42)$ & $(1,146.02)$ & {$[0.45]$} \\
\hline
\end{tabular}

Source: Survey on micro and small enterprises in Uganda, wave October 2017, own calculations. Notes: The table provides summary statistics of baseline data and mean comparisons between treatment group (savings goal calendar) and control group (plain calendar) in Column (5)). Standard deviations are in parenthesis, p-values for differences of means appear in squared brackets. 
Table A.3: Intention-to-Treat Effects on Savings Related Outcomes

\begin{tabular}{|c|c|c|c|c|c|c|c|c|}
\hline & $\begin{array}{l}\text { Savings } \\
\text { Index } \\
(1)\end{array}$ & $\begin{array}{c}\text { Savings } \\
\text { (yes/no) } \\
(2)\end{array}$ & $\begin{array}{c}\text { Savings } \\
\text { Total } \\
(3)\end{array}$ & $\begin{array}{c}\text { Savings } \\
\text { Formal } \\
(4)\end{array}$ & $\begin{array}{l}\text { Savings } \\
\text { Informal } \\
(5)\end{array}$ & $\begin{array}{l}\text { Business } \\
\text { Savings } \\
(6)\end{array}$ & $\begin{array}{l}\text { Frequency } \\
\text { Savings } \\
(7)\end{array}$ & $\begin{array}{c}\text { Savings } \\
\text { Toward Goal } \\
(8)\end{array}$ \\
\hline \multicolumn{9}{|c|}{ Panel A: Unconditional } \\
\hline Savings Goal Calendar & $\begin{array}{l}-.069 \\
(0.086)\end{array}$ & $\begin{array}{c}0.005 \\
(0.026)\end{array}$ & $\begin{array}{l}-356.971 \\
(323.333)\end{array}$ & $\begin{array}{l}-71.124 \\
(128.217)\end{array}$ & $\begin{array}{l}-6.930 \\
(37.263)\end{array}$ & $\begin{array}{l}-51.914 \\
(166.234)\end{array}$ & $\begin{array}{l}-.008 \\
(0.072)\end{array}$ & $\begin{array}{l}-155.559 \\
(140.584)\end{array}$ \\
\hline Obs. & 404 & 404 & 404 & 404 & 404 & 404 & 404 & 404 \\
\hline \multicolumn{9}{|c|}{ Panel B: Control for age, capital stock } \\
\hline Savings Goal Calendar & $\begin{array}{l}-.028 \\
(0.087)\end{array}$ & $\begin{array}{c}0.008 \\
(0.028)\end{array}$ & $\begin{array}{c}-216.094 \\
(307.458)\end{array}$ & $\begin{array}{c}6.123 \\
(127.848)\end{array}$ & $\begin{array}{c}0.686 \\
(37.168)\end{array}$ & $\begin{array}{c}-8.972 \\
(152.940)\end{array}$ & $\begin{array}{l}0.004 \\
(0.068)\end{array}$ & $\begin{array}{l}-119.480 \\
(138.388)\end{array}$ \\
\hline Obs. & 401 & 401 & 401 & 401 & 401 & 401 & 401 & 401 \\
\hline \multicolumn{9}{|c|}{ Panel C: Control for age, capital stock, savings } \\
\hline Savings Goal Calendar & $\begin{array}{l}-.013 \\
(0.086)\end{array}$ & $\begin{array}{c}0.003 \\
(0.028)\end{array}$ & $\begin{array}{l}-209.290 \\
(302.433)\end{array}$ & $\begin{array}{c}11.953 \\
(128.527)\end{array}$ & $\begin{array}{l}-6.349 \\
(36.749)\end{array}$ & $\begin{array}{c}34.005 \\
(147.456)\end{array}$ & $\begin{array}{c}0.01 \\
(0.071)\end{array}$ & $\begin{array}{l}-78.190 \\
(132.529)\end{array}$ \\
\hline Obs. & 401 & 401 & 401 & 401 & 401 & 401 & 401 & 401 \\
\hline
\end{tabular}

Source: Survey on micro and small enterprises in Uganda, waves April and October 2018, own calculations.

Notes: The table shows the 6-months follow-up intention-to-treat effects on savings related outcomes. The savings index provided in Column (1) comprises all variables in the remaining columns. Standard errors in parentheses. ${ }^{*} p<0.1$, ${ }^{* *}$ $p<0.05,{ }^{* * *} p<0.01$ 
Table A.4: Heterogeneity Socio-Economic Characteristics: Savings

\begin{tabular}{|c|c|c|c|c|c|c|c|c|}
\hline & $\begin{array}{l}\text { Savings } \\
\text { Index } \\
(1)\end{array}$ & $\begin{array}{c}\text { Savings } \\
\text { (yes/no) } \\
(2)\end{array}$ & $\begin{array}{c}\text { Savings } \\
\text { Total } \\
(3)\end{array}$ & $\begin{array}{l}\text { Savings } \\
\text { Formal } \\
(4)\end{array}$ & $\begin{array}{l}\text { Savings } \\
\text { Informal } \\
(5)\end{array}$ & $\begin{array}{l}\text { Business } \\
\text { Savings } \\
(6)\end{array}$ & $\begin{array}{l}\text { Frequency } \\
\text { Savings } \\
(7)\end{array}$ & $\begin{array}{c}\text { Savings } \\
\text { Toward Goal } \\
(8)\end{array}$ \\
\hline \multicolumn{9}{|l|}{ Panel A } \\
\hline Savings Goal Calendar & $\begin{array}{l}-.097 \\
(0.13)\end{array}$ & $\begin{array}{l}0.016 \\
(0.038)\end{array}$ & $\begin{array}{c}-522.521 \\
(481.977)\end{array}$ & $\begin{array}{l}-55.122 \\
(173.470)\end{array}$ & $\begin{array}{l}-5.951 \\
(49.549)\end{array}$ & $\begin{array}{l}-118.301 \\
(247.294)\end{array}$ & $\begin{array}{l}0.048 \\
(0.097)\end{array}$ & $\begin{array}{l}-226.481 \\
(210.017)\end{array}$ \\
\hline SGC $*$ Female & $\begin{array}{l}0.149 \\
(0.168)\end{array}$ & $\begin{array}{l}-.018 \\
(0.056)\end{array}$ & $\begin{array}{c}690.602 \\
(563.480)\end{array}$ & $\begin{array}{c}133.185 \\
(255.640)\end{array}$ & $\begin{array}{c}13.985 \\
(74.199)\end{array}$ & $\begin{array}{c}193.735 \\
(291.129)\end{array}$ & $\begin{array}{l}-.095 \\
(0.141)\end{array}$ & $\begin{array}{c}208.968 \\
(271.946)\end{array}$ \\
\hline Obs. & 401 & 401 & 401 & 401 & 401 & 401 & 401 & 401 \\
\hline \multicolumn{9}{|l|}{ Panel B } \\
\hline Savings Goal Calendar & $\begin{array}{l}-.094 \\
(0.1)\end{array}$ & $\begin{array}{l}0.027 \\
(0.033)\end{array}$ & $\begin{array}{l}-317.433 \\
(342.472)\end{array}$ & $\begin{array}{c}-100.782 \\
(147.816)\end{array}$ & $\begin{array}{l}-19.282 \\
(42.878)\end{array}$ & $\begin{array}{c}26.502 \\
(191.253)\end{array}$ & $\begin{array}{l}-.113 \\
(0.074)\end{array}$ & $\begin{array}{l}-241.675 \\
(170.570)\end{array}$ \\
\hline SGC $*$ Higher educated & $\begin{array}{l}0.181 \\
(0.194)\end{array}$ & $\begin{array}{l}-.058 \\
(0.059)\end{array}$ & $\begin{array}{c}301.744 \\
(767.704)\end{array}$ & $\begin{array}{c}331.698 \\
(281.960)\end{array}$ & $\begin{array}{l}50.631 \\
(83.352)\end{array}$ & $\begin{array}{l}-92.821 \\
(373.883)\end{array}$ & $\begin{array}{l}0.332^{* *} \\
(0.141)\end{array}$ & $\begin{array}{c}344.010 \\
(301.465)\end{array}$ \\
\hline Obs. & 401 & 401 & 401 & 401 & 401 & 401 & 401 & 401 \\
\hline \multicolumn{9}{|l|}{ Panel C } \\
\hline Savings Goal Calendar & $\begin{array}{c}0.01 \\
(0.101)\end{array}$ & $\begin{array}{l}0.024 \\
(0.041)\end{array}$ & $\begin{array}{c}-198.572 \\
(313.240)\end{array}$ & $\begin{array}{l}-27.376 \\
(160.565)\end{array}$ & $\begin{array}{c}48.869 \\
(53.548)\end{array}$ & $\begin{array}{l}-21.679 \\
(184.758)\end{array}$ & $\begin{array}{c}0.026 \\
(0.068)\end{array}$ & $\begin{array}{c}-219.199 \\
(176.861)\end{array}$ \\
\hline $\mathrm{SGC} *$ Married & $\begin{array}{l}-.072 \\
(0.171)\end{array}$ & $\begin{array}{l}-.029 \\
(0.055)\end{array}$ & $\begin{array}{l}-38.249 \\
(667.458)\end{array}$ & $\begin{array}{c}61.408 \\
(249.492)\end{array}$ & $\begin{array}{c}-90.209 \\
(73.555)\end{array}$ & $\begin{array}{c}32.476 \\
(327.486)\end{array}$ & $\begin{array}{l}-.039 \\
(0.134)\end{array}$ & $\begin{array}{c}162.918 \\
(291.634)\end{array}$ \\
\hline Obs. & 401 & 401 & 401 & 401 & 401 & 401 & 401 & 401 \\
\hline \multicolumn{9}{|l|}{ Panel D } \\
\hline Savings Goal Calendar & $\begin{array}{l}0.082 \\
(0.136)\end{array}$ & $\begin{array}{c}0.013 \\
(0.066)\end{array}$ & $\begin{array}{c}49.894 \\
(529.028)\end{array}$ & $\begin{array}{c}106.413 \\
(344.241)\end{array}$ & $\begin{array}{c}49.974 \\
(75.107)\end{array}$ & $\begin{array}{c}217.338 \\
(316.996)\end{array}$ & $\begin{array}{c}0.012 \\
(0.139)\end{array}$ & $\begin{array}{l}-141.903 \\
(225.113)\end{array}$ \\
\hline SGC * Financial literacy & $\begin{array}{l}-.132 \\
(0.17)\end{array}$ & $\begin{array}{l}-.006 \\
(0.072)\end{array}$ & $\begin{array}{l}-313.400 \\
(680.238)\end{array}$ & $\begin{array}{l}-114.782 \\
(371.651)\end{array}$ & $\begin{array}{l}-60.895 \\
(85.462)\end{array}$ & $\begin{array}{l}-258.637 \\
(372.996)\end{array}$ & $\begin{array}{l}-.009 \\
(0.161)\end{array}$ & $\begin{array}{c}19.550 \\
(272.888)\end{array}$ \\
\hline Obs. & 401 & 401 & 401 & 401 & 401 & 401 & 401 & 401 \\
\hline \multicolumn{9}{|l|}{ Panel E } \\
\hline Savings Goal Calendar & $\begin{array}{l}-.035 \\
(0.084)\end{array}$ & $\begin{array}{l}0.015 \\
(0.033)\end{array}$ & $\begin{array}{l}-157.900 \\
(242.707)\end{array}$ & $\begin{array}{l}-52.508 \\
(127.197)\end{array}$ & $\begin{array}{c}9.999 \\
(44.185)\end{array}$ & $\begin{array}{c}74.660 \\
(142.302)\end{array}$ & $\begin{array}{l}-.100 \\
(0.075)\end{array}$ & $\begin{array}{l}-79.911 \\
(100.433)\end{array}$ \\
\hline SGC * Sales & $\begin{array}{l}0.002 \\
(0.194)\end{array}$ & $\begin{array}{l}-.012 \\
(0.059)\end{array}$ & $\begin{array}{l}-210.959 \\
(695.150)\end{array}$ & $\begin{array}{c}103.731 \\
(280.988)\end{array}$ & $\begin{array}{l}-29.516 \\
(75.888)\end{array}$ & $\begin{array}{l}-223.120 \\
(344.452)\end{array}$ & $\begin{array}{l}0.26^{*} \\
(0.152)\end{array}$ & $\begin{array}{l}-140.425 \\
(322.322)\end{array}$ \\
\hline Obs. & 401 & 401 & 401 & 401 & 401 & 401 & 401 & 401 \\
\hline \multicolumn{9}{|l|}{ Panel F } \\
\hline Savings Goal Calendar & $\begin{array}{l}0.126 \\
(0.137)\end{array}$ & $\begin{array}{l}-.004 \\
(0.046)\end{array}$ & $\begin{array}{c}698.586 \\
(497.882)\end{array}$ & $\begin{array}{c}255.609 \\
(223.093)\end{array}$ & $\begin{array}{c}21.860 \\
(67.180)\end{array}$ & $\begin{array}{c}159.725 \\
(291.518)\end{array}$ & $\begin{array}{l}-.033 \\
(0.097)\end{array}$ & $\begin{array}{c}286.307 \\
(226.297)\end{array}$ \\
\hline SGC $*$ Business experience & $\begin{array}{l}-.014 \\
(0.011)\end{array}$ & $\begin{array}{l}0.001 \\
(0.004)\end{array}$ & $\begin{array}{c}-83.179^{* *} \\
(41.380)\end{array}$ & $\begin{array}{l}-22.538 \\
(15.878)\end{array}$ & $\begin{array}{l}-2.180 \\
(4.933)\end{array}$ & $\begin{array}{l}-14.619 \\
(27.769)\end{array}$ & $\begin{array}{c}0.003 \\
(0.009)\end{array}$ & $\begin{array}{c}-37.063^{*} \\
(19.865)\end{array}$ \\
\hline Obs. & 401 & 401 & 401 & 401 & 401 & 401 & 401 & 401 \\
\hline \multicolumn{9}{|l|}{ Panel G } \\
\hline Savings Goal Calendar & $\begin{array}{l}0.055 \\
(0.133)\end{array}$ & $\begin{array}{l}-.025 \\
(0.046)\end{array}$ & $\begin{array}{c}395.690 \\
(479.578)\end{array}$ & $\begin{array}{c}185.173 \\
(225.237)\end{array}$ & $\begin{array}{c}1.265 \\
(65.823)\end{array}$ & $\begin{array}{c}95.250 \\
(278.138)\end{array}$ & $\begin{array}{l}-.014 \\
(0.101)\end{array}$ & $\begin{array}{c}188.581 \\
(210.542)\end{array}$ \\
\hline SGC $*$ Firm age & $\begin{array}{l}-.007 \\
(0.011)\end{array}$ & $\begin{array}{l}0.003 \\
(0.004)\end{array}$ & $\begin{array}{l}-53.077 \\
(40.320)\end{array}$ & $\begin{array}{l}-15.451 \\
(15.748)\end{array}$ & $\begin{array}{l}-.284 \\
(4.695)\end{array}$ & $\begin{array}{l}-7.568 \\
(26.383)\end{array}$ & $\begin{array}{l}0.002 \\
(0.01)\end{array}$ & $\begin{array}{l}-26.328 \\
(18.934)\end{array}$ \\
\hline Obs. & 401 & 401 & 401 & 401 & 401 & 401 & 401 & 401 \\
\hline \multicolumn{9}{|l|}{ Panel H } \\
\hline Savings Goal Calendar & $\begin{array}{l}0.044 \\
(0.101)\end{array}$ & $\begin{array}{l}0.043 \\
(0.043)\end{array}$ & $\begin{array}{l}140.684 \\
(267.331)\end{array}$ & $\begin{array}{c}17.928 \\
(126.340)\end{array}$ & $\begin{array}{l}-18.441 \\
(48.823)\end{array}$ & $\begin{array}{l}159.537 \\
(181.645)\end{array}$ & $\begin{array}{l}-.032 \\
(0.094)\end{array}$ & $\begin{array}{l}-47.633 \\
(100.925)\end{array}$ \\
\hline SGC $*$ Profit & $\begin{array}{l}-.176 \\
(0.168)\end{array}$ & $\begin{array}{l}-.064 \\
(0.053)\end{array}$ & $\begin{array}{l}-764.070 \\
(603.238)\end{array}$ & $\begin{array}{c}-91.559 \\
(242.188)\end{array}$ & $\begin{array}{c}19.290 \\
(73.833)\end{array}$ & $\begin{array}{l}-352.996 \\
(323.056)\end{array}$ & $\begin{array}{c}0.069 \\
(0.143)\end{array}$ & $\begin{array}{l}-210.630 \\
(262.308)\end{array}$ \\
\hline Obs. & 400 & 400 & 400 & 400 & 400 & 400 & 400 & 400 \\
\hline \multicolumn{9}{|l|}{ Panel I } \\
\hline Savings Goal Calendar & $\begin{array}{l}-.091 \\
(0.124)\end{array}$ & $\begin{array}{c}0.017 \\
(0.042)\end{array}$ & $\begin{array}{c}-237.878 \\
(401.299)\end{array}$ & $\begin{array}{l}-36.606 \\
(163.713)\end{array}$ & $\begin{array}{l}-69.442 \\
(47.276)\end{array}$ & $\begin{array}{c}4.298 \\
(211.502)\end{array}$ & $\begin{array}{l}0.041 \\
(0.105)\end{array}$ & $\begin{array}{c}-99.613 \\
(184.278)\end{array}$ \\
\hline SGC $*$ Service sector & $\begin{array}{l}-.227 \\
(0.253)\end{array}$ & $\begin{array}{l}-.002 \\
(0.086)\end{array}$ & $\begin{array}{c}31.308 \\
(671.700)\end{array}$ & $\begin{array}{l}-266.725 \\
(435.527)\end{array}$ & $\begin{array}{c}-27.559 \\
(112.100)\end{array}$ & $\begin{array}{l}-361.955 \\
(298.490)\end{array}$ & $\begin{array}{l}-.430 \\
(0.277)\end{array}$ & $\begin{array}{l}-278.909 \\
(356.143)\end{array}$ \\
\hline $\mathrm{SGC} *$ Retail sector & $\begin{array}{l}0.221 \\
(0.192)\end{array}$ & $\begin{array}{l}-.025 \\
(0.059)\end{array}$ & $\begin{array}{c}108.678 \\
(773.416)\end{array}$ & $\begin{array}{c}153.435 \\
(274.721)\end{array}$ & $\begin{array}{c}166.676^{* *} \\
(84.491)\end{array}$ & $\begin{array}{c}152.410 \\
(370.594)\end{array}$ & $\begin{array}{l}0.042 \\
(0.144)\end{array}$ & $\begin{array}{c}34.593 \\
(334.185)\end{array}$ \\
\hline SGC * Other sector & $\begin{array}{l}0.281 \\
(0.627)\end{array}$ & $\begin{array}{l}0.008 \\
(0.055)\end{array}$ & $\begin{array}{l}-729.850 \\
(2520.246)\end{array}$ & $\begin{array}{c}656.784 \\
(1136.355)\end{array}$ & $\begin{array}{c}380.451 \\
(240.329)\end{array}$ & $\begin{array}{l}-595.310 \\
(1361.999)\end{array}$ & $\begin{array}{l}-.058 \\
(0.294)\end{array}$ & $\begin{array}{l}-223.568 \\
(1260.137)\end{array}$ \\
\hline Obs. & 401 & 401 & 401 & 401 & 401 & 401 & 401 & 401 \\
\hline
\end{tabular}

Source: Survey on micro and small enterprises in Uganda, waves 2017-2018, own calculations.

Notes: The table presents a heterogeneity analysis, with the treatment being interacted with an indicator for: whether the business owner is a women (Panel A), more than A-level education (Panel B), being married (Panel C), financial literacy level above sample median (Panel D), sales above sample median (Panel E), continuous measure of business experience (Panel F), continuous measure of firm age (Panel G), profit above sample median (Panel H), industry sector (Panel I). Standard errors in parentheses. ${ }^{*} p<0.1,{ }^{* *}$ $p<0.05,{ }^{* * *} p<0.01$. 


\section{Appendix B}

Table B.1: Variable Definitions of Secondary Outcomes

\begin{tabular}{|c|c|}
\hline Variable & Survey Question \\
\hline \multicolumn{2}{|l|}{ Investment } \\
\hline New Investment (yes/no) & Bought new investment in $\mathrm{t}+1$ \\
\hline New Investment Amount & Amount of new investment bought in $t+1$ \\
\hline Inventory Amount & Inventory Amount \\
\hline Planned Investment (yes/no) & Planning of new investment \\
\hline Planned Investment Amount & Amount of planned new investment \\
\hline Planned hiring (yes/no) & Planned hiring of employees \\
\hline Planned hiring Number & Number of new employees planned to hire \\
\hline \multicolumn{2}{|l|}{ Costs } \\
\hline Costs Raw Materials & $\begin{array}{l}\text { Please consider now your total expenditures for ALL raw materials: How } \\
\text { much did you spend on raw materials in the last four weeks? }\end{array}$ \\
\hline Costs Finished Goods & $\begin{array}{l}\text { Please consider your total expenditures for ALL the finished goods you } \\
\text { sell without transformations: How much did you spend on finished goods } \\
\text { in the last four weeks? }\end{array}$ \\
\hline Covers expenditures using & $\begin{array}{l}\text { How do you usually cover your expenditures for raw materials and fin- } \\
\text { ished goods? }\end{array}$ \\
\hline ... savings & Own savings/profits? \\
\hline ... loans & Loan from suppliers [goods on credit] \\
\hline ... advance payments & Advance payments of customers \\
\hline Other expenditures & $\begin{array}{l}\text { What are the other expenditures of your business over the past twelve } \\
\text { months? }\end{array}$ \\
\hline \multicolumn{2}{|r|}{ T } \\
\hline Applied for Formal Loan & $\begin{array}{l}\text { Have you applied for a loan/credit at a formal financial institution? [e.g. } \\
\text { from a bank, microfinance institution, SACCO] }\end{array}$ \\
\hline Applied for Informal Loan & $\begin{array}{l}\text { Have you applied for an informal loan/credit from any other source? [e.g. } \\
\text { friends, relatives, business partners, moneylenders] }\end{array}$ \\
\hline Loan Amount & Formal or informal credit amount \\
\hline \multicolumn{2}{|l|}{ Perceptions } \\
\hline Reached Goal & $\begin{array}{l}\text { Did you reach your saving goal amount? Meaning, did you save the whole } \\
\text { amount you wanted to save? }\end{array}$ \\
\hline Bought Goal & Did you actually buy what was for your saving goal? \\
\hline \multicolumn{2}{|c|}{ Business Practices and Financial Awareness } \\
\hline Financial record keeping & Do you keep financial records in your business? \\
\hline \multicolumn{2}{|l|}{ Thought about... } \\
\hline ... investing in business & How much have you thought about investing in your business? \\
\hline ... how to grow business & How much have you thought about how you can grow your business? \\
\hline Setting aside money & $\begin{array}{l}\text { How often do you set money aside for your business but it gets used for } \\
\text { household/private expenses? }\end{array}$ \\
\hline Budget Plan & How often do you make a household budget? \\
\hline Spend money & How often do you spend your money according to your budget? \\
\hline Pressure sharing money & $\begin{array}{l}\text { I feel pressure to share extra business income with other household mem- } \\
\text { bers. }\end{array}$ \\
\hline
\end{tabular}


Table B.2: Intention-to-Treat Effects on Investment Related Outcomes

\begin{tabular}{lcccccccc}
\hline \hline & $\begin{array}{c}\text { New } \\
\text { Investment } \\
(\text { yes/no) } \\
(1)\end{array}$ & $\begin{array}{c}\text { New } \\
\text { Investment } \\
\text { Amount } \\
(2)\end{array}$ & $\begin{array}{c}\text { Inventory } \\
\text { Amount } \\
(3)\end{array}$ & $\begin{array}{c}\text { New } \\
\text { Products } \\
(\text { yes/no) } \\
(4)\end{array}$ & $\begin{array}{c}\text { Planned } \\
\text { Investment } \\
(\text { yes/no) } \\
(5)\end{array}$ & $\begin{array}{c}\text { Planned } \\
\text { Investment } \\
\text { Amount } \\
(6)\end{array}$ & $\begin{array}{c}\text { Planned } \\
\text { hiring } \\
(\text { yes } / \text { no }) \\
(7)\end{array}$ & $\begin{array}{c}\text { Planned } \\
\text { hiring } \\
\text { Number } \\
(8)\end{array}$ \\
\hline Savings Goal Calendar & 0.024 & 32.311 & $1536.572^{* *}$ & -.018 & -.030 & 1199.651 & 0.033 & 0.074 \\
& $(0.046)$ & $(54.307)$ & $(759.879)$ & $(0.028)$ & $(0.042)$ & $(951.888)$ & $(0.037)$ & $(0.072)$ \\
Obs. & 439 & 439 & 439 & 439 & 401 & 439 & 400 & 438 \\
\hline \hline
\end{tabular}

Source: Survey on micro and small enterprises in Uganda, waves April and October 2018, own calculations.

Notes: The table shows the 6-months follow-up intention-to-treat effects on investment related outcomes. Standard errors in parentheses. ${ }^{*} p<0.1,{ }^{* *} p<0.05,{ }^{* * *} p<0.01$.

Table B.3: Intention-to-Treat Effects on Cost Related Outcomes

\begin{tabular}{|c|c|c|c|c|c|c|}
\hline & \multirow{2}{*}{$\begin{array}{c}\text { Costs } \\
\text { Raw Materials } \\
\text { Amount } \\
(1)\end{array}$} & \multirow{2}{*}{$\begin{array}{c}\text { Costs } \\
\text { Finished Goods } \\
\text { Amount } \\
(2)\end{array}$} & \multicolumn{3}{|c|}{ Covers expenditures using ... } & \multirow{2}{*}{$\begin{array}{c}\text { Other } \\
\text { expenditures } \\
\text { Amount } \\
(6)\end{array}$} \\
\hline & & & $\begin{array}{l}\text { savings } \\
\text { (yes/no) } \\
(3)\end{array}$ & $\begin{array}{c}\text { loans } \\
\text { (yes/no) } \\
(4)\end{array}$ & $\begin{array}{c}\text { advance payments } \\
\text { (yes/no) } \\
(5)\end{array}$ & \\
\hline Savings Goal Calendar & $\begin{array}{c}-46.849 \\
(428.364)\end{array}$ & $\begin{array}{c}1096.567 \\
(1471.894)\end{array}$ & $\begin{array}{l}-.002 \\
(0.009)\end{array}$ & $\begin{array}{c}0.031 \\
(0.047)\end{array}$ & $\begin{array}{l}0.0006 \\
(0.043)\end{array}$ & $\begin{array}{l}18.205 \\
(63.112)\end{array}$ \\
\hline Obs. & 397 & 400 & 400 & 400 & 400 & 401 \\
\hline
\end{tabular}

Source: Survey on micro and small enterprises in Uganda, waves April and October 2018, own calculations. Notes: The table shows the 6-months follow-up intention-to-treat effects on cost related outcomes. Standard errors in parentheses. ${ }^{*} p<0.1,{ }^{* *} p<0.05,{ }^{* * *} p<0.01$.

Table B.4: Intention-to-Treat Effects on Borrowing Related Outcomes

\begin{tabular}{lccc}
\hline \hline & $\begin{array}{c}\text { Applied for Formal Loan } \\
\text { (yes/no) } \\
(1)\end{array}$ & $\begin{array}{c}\text { Applied for Informal Loan } \\
\text { (yes/no) } \\
(2)\end{array}$ & $\begin{array}{c}\text { Loan } \\
\text { Amount } \\
(3)\end{array}$ \\
\hline Savings Goal Calendar & $0.057^{*}$ & 0.007 & 261.446 \\
Obs. & 401 & $(0.032)$ & $(228.395)$ \\
\hline \hline \multicolumn{2}{l}{ Source: Survey on micro and small enterprises in Uganda, waves April and October 2018, own } \\
calculations. \\
Notes: The table shows the 6-months follow-up intention-to-treat effects on borrowing related \\
outcomes. Standard errors in parentheses. ${ }^{*} p<0.1,{ }^{* *} p<0.05,{ }^{* * *} p<0.01$.
\end{tabular}

Table B.5: Intention-to-Treat Effects on Perceptions Related Outcomes

\begin{tabular}{lcc}
\hline \hline & $\begin{array}{c}\text { Reached Goal } \\
(1)\end{array}$ & $\begin{array}{c}\text { Bought Goal } \\
(2)\end{array}$ \\
\hline Savings Goal Calendar & $-.076^{*}$ & $-.083^{*}$ \\
& $(0.045)$ & $(0.045)$ \\
Obs. & 397 & 397 \\
\hline \hline Source: Survey on micro and small enterprises in \\
Uganda, waves April and October 2018, own calcula- \\
tions. \\
Notes: The table shows the 6-months follow-up \\
intention-to-treat effects on outcomes related to percep- \\
tions. Standard errors in parentheses. ${ }^{*} p<0.1,{ }^{* *}$ \\
$p<0.05,{ }^{* * *} p<0.01$.
\end{tabular}


Table B.6: Intention-to-Treat Effects on Business Practices and Financial Awareness Related Outcomes

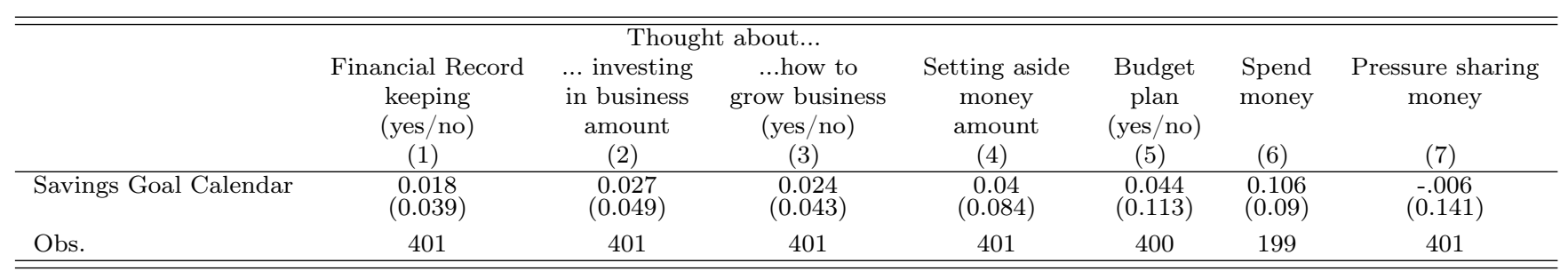

Source: Survey on micro and small enterprises in Uganda, waves April and October 2018, own calculations.

Notes: The table shows the 6-months follow-up intention-to-treat effects on business practices and financial awareness related outcomes. Standard errors in parentheses. ${ }^{*} p<0.1,{ }^{* *} p<0.05,{ }^{* * *} p<0.01$. 